\title{
ALGUNS PROBLEMAS CONCEITUAIS E ESTRUTURAIS DO COSMOPOLITISMO GLOBAL*
}

\section{Hauke Brunkhorst}

\author{
Tradução de Sebastiāo Nascimento
}

Não há muito propósito em discutir se deveríamos ou não adotar uma ordem pós-nacional e cosmopolita. Já a temos, e o que nos resta é assumir posiçôes a favor ou contra a - atualmente - ubíqua (e, em certas partes do mundo, bastante poderosa) presença de um Estado inscrito no interior da ordem mundial cosmopolita.

Uma das lendas oriundas das escolas de pensamento de Eric Voegelin ou Carl Schmitt era a tese segundo a qual o Estado seria uma invenção moderna surgida no século XVI ou XVII. Mas a formação e a transformação do Estado têm uma longa história, que remonta às primeiras sociedades com algum nível de especialização no recurso ao poder coercitivo (Tilly, 2007, p. 4). O Estado nacional que não deve ser confundido com o Estado-nação homogêneo, que já não existe - existiu durante o

* Texto apresentado no Simpósio realizado na cidade de Skagen, Dinamarca, "Present futures and future presents: World State scenarios for the 21st Century". final do século XIX numa porção reduzida (mas poderosa) no noroeste do globo, oriundo em grande medida do período da Reforma Protestante, mas contando com raízes profundas na história medieval, chegando a se tornar a forma política dominante na Europa ao longo do século XIX e globalizando-se durante a segunda metade do século XX (Idem, 1990). ${ }^{1}$

Entretanto, no início do século XIX, a cidade-estado europeia ainda sobrevivia, ao lado do Estado territorial, que já havia se tornado muito mais forte. O Tratado Federativo Alemão, de 1815, foi um acordo entre "príncipes soberanos e [...] cidades livres" (Preâmbulo e Artigo 1º). Isso se repetiu no Protocolo Final da Conferência Ministerial de Viena (Wiener Schlussakte) de 1820, que representou novamente um acordo entre Estados territoriais (monárquicos) e cidades-estados (republicanas) no mesmo ano em que Hegel concluía sua grandiosa afirmação do Estado nacional moderno, Os Fun- 
damentos da Filosofia do Direito (Grundlinien der Philosophie des Rechts). ${ }^{2}$ Contudo, Hegel escreveu sobre a essência do Estado e não sobre sua forma efetiva, e nisso tinha razão. Com a exceção de uns poucos casos singulares e eminentemente folclóricos ou nominais, nada restou no século XX das cidades-estados, que haviam sido livres, republicanas e verdadeiros pilares da acumulação de capital por centenas de anos. Em 1820, parecia evidente que não havia alternativa ao Estado nacional, que buscava o monopólio da organização política. Hoje, o processo consideravelmente acelerado de acumulação de capital explodiu os - hoje, reconhecidamente - estreitos muros das cidades, pois necessitava de um poder operativo mais amplo e organizado em maior escala. Esse poder era o Estado nacional, que havia sido "aperfeiçoado" por "todas as revoluçôes" que o haviam tentado "romper", sem sucesso. ${ }^{3}$ Mas essa entidade poderosa, que jamais chegou a encarnar a santíssima trindade de Jellinek, composta por governo (Staatsgewalt), território (Staatsgebiet) e povo (Staatsvolk) - apesar de que, com certa distância, chegasse ainda a guardar alguma semelhança com o modelo -, teve uma duração bastante curta, como veremos.

No início do século XXI, vivemos em uma sociedade mundial de pleno direito, composta por um sistema global de Estados, organizações mundiais, meios de comunicação de alcance global, mercados mundiais, política mundial e problemas que afetam igualmente a todos em todo o mundo. ${ }^{4}$ Nessa sociedade mundial, "o poder de Estados financeira e militarmente fortes, como Japão e Alemanha, continua e se expandir" e seu poder já é muito maior do que de Estados mais pobres e militarmente fortes (como China, antes da explosão de sua economia de mercado reformada, ou Irã e Cuba atualmente) e ainda maior que o de Estados fortes nos dois sentidos (como Grã-Bretanha). Além disso, já não é um mundo de Estados que se apoiam no poder coercitivo e no capital (com peso cada vez maior no capital), mas um mundo no qual esses Estados têm de dividir seu poder com "o capital multinacional, representado pelo comércio de drogas, armas, eletrônicos, publicaçōes, petróleo ou açōes, o qual tem assumido considerável poder e mobilidade de forma parcialmente independente dos Estados cujos residentes criaram e acumularam (esse mesmo) capital" (Tilly, 1995, p. 26). Num mundo assim, a noção tradicional (e, a propósito, conceitualmente contraditória [Kelsen, (1920) 1981]) de soberania estatal não mais se reveste de qualquer importância, em vista de qualquer sentido do termo soberania (como na definição de Hobbes da soberania como o "Deus terreno" monoteísta).

A construção filosófica hobbesiana do Leviatã estava muito além da realidade política e constitucional europeia e, em especial, inglesa naquele ou em qualquer outro período. Aquilo que a constitui continua a ser um mito político altamente influente. Contudo, os vitoriosos da Revolução Inglesa não foram os partidários do príncipe soberano, James I e seu filho decapitado, ou o filósofo do célebre diálogo hobbesiano com o estudante do direito consuetudinário (Hobbes, 1971), mas os críticos da soberania absoluta, os juristas do direito consuetudinário, Sir Edward Coke, Mathew Hayle e seus estudantes (Berman, 2004). Jamais houve um Leviatã que sustentasse a paz jurídica, como na teoria pura de Hobbes. Tampouco um poder soberano pacificador internamente incontestado, 5 nem um poder que não estivesse sob a lei (pelo menos sob a lei divina e natural) e, sob alguns aspectos, já se tratava de um poder constitucionalizado (vinculado a um procedimento legislativo específico, conselhos consultivos etc.), apoiado numa certa separação de poderes (por exemplo, entre rei, nobreza e clero, pares e parlamento como a corte suprema etc.) (Idem). Ademais, e isso conduz a uma das teses centrais deste artigo, não houve primeiro e originalmente um pluriverso de Leviatãs e só então um problema de direito internacional de segunda ordem, como na visão construtivista da teoria contratual da formação do Estado, mas, ao contrário, desde o início do Estado moderno, ocorreu uma co-originalidade de uma ordem jurídica internacional ou cosmopolita (com alguns aspectos de estatalidade universal) e uma ordem jurídica de Estados particulares, tais como o próprio Estado nacional, que foi inventado primeiramente pela Revolução Inglesa (ver "Um universal evolucionário", adiante).

Em ambos os extremos do espectro histórico, o paradigma do Estado nacional (ou mesmo o mito do Estado-nação homogêneo) está desmoronando, 
em sua origem no passado e em sua forma presente. A sociedade mundial atual não é o mero resultado dos efeitos de problemas globais: esses problemas são hoje não só percebidos mas também definidos como problemas comuns a toda a humanidade, e isso é possível apenas porque a sociedade mundial já é uma sociedade normativamente integrada (Stichweh, 2004).

Atualmente, a nova ordem cosmopolita inclui: (1) a permanentemente crescente juridicização da sociedade mundial (Bogdandy et al., 2009), (2) a emergência de algum tipo de hierarquia normativa (Peters, 2006, vol. 19; Fassbender, 2009, pp. 103ss) (como no caso nacional dos Estados Unidos ou no caso da União Europeia (EU) se tornando compatível com um certo tipo de "pluralismo constitucional”) (Halberstam, 2008), e (3) o acoplamento estrutural dos sistemas jurídico e político mundiais (Di Fabio, 1998, pp. 106ss). Portanto, a atual ordem cosmopolita já é uma ordem constitucional, ao mesmo tempo cosmopolita e marcada por fortes elementos de estatalidade em níveis pós-nacionais. ${ }^{6}$ A estatalidade de uma organização internacional distingue-se, nesse caso, de uma mera organização intergovernamental em razão do seguinte critério: uma organização internacional somente será uma organização similar ao Estado se, e apenas se, não apenas corrigir uma função estatal específica, mas também a suplantar (Albert, 2005, p. 229). Bons exemplos são o sistema de tribunais internacionais (Bogdandy e Venzke, 2009), a debilmente institucionalizada, no mais das vezes informal, mas regular e estreita cooperação entre órgãos executivos (do G20 ao Comitê de Supervisão Bancária da Basileia, passando pelo Processo de Bolonha) (Brunkhorst, 2007) ou o âmbito regional da União Europeia, onde até mesmo a legitimação democrática atualmente se apoia numa complexa "rede de reciprocidade entre os Estados Membros e a UE" (Ley, 2010, p. 170, ver também p. 169). Organizaçôes internacionais como a ONU, a OIT, a OEA, a União Africana (UA) e a União Europeia "assumiram [...] funçôes anteriormente desempenhadas por governos" (Halberstam, 2010, p. 3). Trata-se de funções de governo e não a nebulosa chamada de governança, precisamente porque legisladores internacionais ou órgãos judiciais são agentes res- ponsáveis, com nomes e endereços, mesmo que por vezes procurem operar (como chefóes mafiosos) nas sombras, longe do escrutínio público. ${ }^{7}$ Essa ordem mundial cosmopolita, em seu cerne institucional, foi delineada e efetivada após a Primeira Guerra Mundial, sem sucesso, e posteriormente de forma bem-sucedida, entre 1941 e 1951; e a partir de 1989, tornou-se a ordem cosmopolita de todo o planeta. Contudo, está longe de ser democrática, pois não é constitucionalizada plenamente, , como veremos adiante.

Abordando simultaneamente ambos os extremos no espectro histórico do Estado moderno, este artigo defende uma mudança de paradigma na Teoria do Estado moderno. Minha tese é que o Estado nacional constitui um caso liminar de estatalidade, um caso histórico bastante específico, que de modo algum representa a forma perfeita do Estado ou o telos de três mil anos de evolução estatal.

$\mathrm{Na}$ primeira parte, abordarei o conceito de "cosmopolitismo". Em contraste com a visão eurocêntrica de que o cosmopolitismo teve origem no estoicismo da Grécia e da Roma antigas. Demonstrarei que o cosmopolitismo não foi exclusivamente uma invenção europeia e que os ideais cosmopolitas antigos já incluíam alguns elementos formais que se tornariam importantes muito depois, tendo sido mesmo constitutivos para a noção moderna de auto-organização democrática (seção "Um universal evolucionário". Procurarei desenvolver a tese da coevolução da estatalidade cosmopolita e nacional (seção "Coevolução das estatalidades universal e nacional”), que se desenvolvera em estágios diferentes desde as Revoluçôes Papal (seção "O primeiro Estado cosmopolita e a liberdade de associação) e Protestante (seção "Liberdade do ser humano individual"). Esses elementos formais incluem o vínculo interno entre o direito universal e as normas de regulação procedimental, que somente viriam a ser implementadas por regimes políticos modernos a partir das revoluçôes constitucionais do final do século XVIII (seção "Avanços revolucionários”). A seguir, discutirei o retorno do cosmopolitismo jurídico e político no século XX. Minha tese sustenta que o cosmopolitismo século XX (a denominação é irrelevante para o argumento) inventou uma nova ideia de liberdade (seção "Uma nova ideia de liber- 
dade"), que está contida na Carta da ONU (seção "Constitucionalização revolucionária e evolucionária”) e na Declaração Universal dos Direitos Humanos de 1948 (seção "Dignidade igualitária e democracia social de massa"), e que vai muito além das ideias de 1789. Por fim, a última seção se dedica à finalização temporária do cosmopolitismo global e a seus problemas estruturais, em especial, o quase insolúvel problema de sua democratização (seção "Democracia perdida?").

\section{Um universal evolucionário}

O cosmopolitismo é um projeto antigo e de forma alguma algo especificamente europeu, exceto talvez pela noção que combina o cosmos com a pólis, o universo com a sociedade civil. Para os primeiros filósofos estoicos gregos, o cosmos era uma pólis, pois se tratava de uma ordem racional perfeita, e viver de acordo com ela era a finalidade (o telos) do animal político (zoon politikon). Apesar disso, algo que normalmente se negligencia é o fato de que o cosmopolitismo não fora uma invenção filosófica unicamente de filósofos gregos e romanos. Pelo contrário, havia sido inventado durante a Era Axial, entre 800 e 200 a.C., em vários lugares diferentes e relativamente independentes uns em relação aos outros. Quando a questão já estava estabelecida, o termo - seja cosmopolis, civitas maxima, res publica universalis, monarquia universal ou ecclesia universalis - foi introduzido pela primeira vez no século IV a.C, por filósofos gregos, posteriormente refinado e reinterpretado por filósofos romanos e cristãos e, a seu turno, pelos filósofos do Iluminismo.

Em razão de terem sido inventadas independentemente em diferentes regiōes do globo, de Beijing a Roma, e em contextos religiosos e profanos muito diversos, as ideias cosmopolitas devem ser abordadas como um universal evolucionário ou como um ganho evolucionário (Parsons, 1964). ${ }^{8}$ Assim como o olho, o cérebro, o parentesco, os sistemas de crença religiosa, a estratificação social, a diferenciação funcional, os impérios, os Estados, as constituições ou (se seguimos Parsons) até mesmo a democracia, o cosmopolitismo é uma invenção múltipla da evolução. Esteve no princípio estreitamente associada à emergência de visóes de mundo religiosas e filosóficas abrangentes e altamente racionalizadas e, ao mesmo tempo, à emergência do imperialismo, da estratificação das classes sociais e da diferenciação entre centros urbanos e periferias rurais. Paradigmático é o uso de urbs no singular para se referir à cidade de Roma tanto nos tempos do classicismo pagão como no moderno catolicismo, e orbis para o restante do mundo.

Todas as versões do cosmopolitismo são definidas pelo mesmo conjunto de ideias básicas, e todas elas também foram articuladas inicialmente pelo budismo, assim como pelas filosofias cínica e estoica, pelo confucionismo, judaísmo, taoismo e zoroastrismo, bramanismo e cristianismo. O cosmopolitismo clássico envolve:

1. A ideia de uma comunidade universal, submetida à única lei básica universal, a Regra de Ouro, que se encontra no centro de todas as principais ordens políticas, religiosas e jurídicas daquele período (Berman, 2005, p. 79).

2. Um conjunto de regras procedimentais para a solução formalmente institucionalizada de conflitos.

3. Um tipo (possivelmente o primeiro) de direito subjetivo a ouvir e a ser ouvido, estendido a todas as partes num dado caso e também a "apresentar evidências para sustentar os argumentos apresentados em favor de uma posição ou contra ela" (no direito romano, audi alteram partem) [Idem, ibidem].

4. Leis básicas universais: regras procedimentais e garantias subjetivas (de ouvir e apresentar razões) que conformam a instituição do juizo equânime e do tribunal imparcial, que poderia ser estendido até mesmo aos estrangeiros, como no caso do ius gentium romano. ${ }^{9}$

5. Princípios, métodos e garantias universais, implicando, ademais, que sua aplicação não se restrinja a ritos judiciais, mas que também se estenda a procedimentos legislativos e administrativos.

6. Princípios universais que não se restrinjam ao direito oficial ou público, mas que também sejam aplicáveis a "soluções oficiosas e informais de conflitos no seio de associações de qual- 
quer natureza e também entre elas" (famílias, vizinhanças, ofícios, corporações, sociedades religiosas, grupos étnicos, nações, culturas e civilizaçōes, que se vêm chocando desde o Paleolítico Inferior) [Idem].

Mesmo em sociedades profundamente desiguais, essas regras asseguravam um minimo de igualdade, garantindo que conflitos fossem resolvidos pelo uso de meios legais, o que nem sempre foi o caso nas relações entre as camadas superiores e inferiores da sociedade. $\mathrm{O}$ direito romano era civil, ou seja, era usado para coordenar e estabilizar as relações internas das classes dominantes, enquanto as outras classes estavam sujeitas a medidas meramente coercitivas (Wesel, 1997, p. 156). Como todos os imperadores, também os romanos sabiam: "a coerção funciona" (Tilly, 1990, p. 70). Assim, as noções de justiça universal e cosmopolitismo sustentavam as "ideias abstratas" (Hegel) nos tempos antigos e, ao menos para as classes baixas, quase invariavelmente careciam de qualquer impacto real, úteis, na melhor das hipóteses, para a boa vida dos filósofos.

Mesmo que o pensamento cosmopolita tenha sido, desde o princípio, destinado à implementação institucional e mesmo que tenha tido consideráveis consequências institucionais nas diferentes regiōes do mundo antigo, especialmente para o desenvolvimento jurisdicional, o cosmopolitismo primevo das antigas sociedades políticas e impérios estava apenas superficialmente ligado ao poder político e a efeitos de caráter jurídico. Se pusermos de lado algumas versões gregas mais politicamente carregadas, dirigidas contra um paroquialismo da pólis de extração platônica, o cosmopolitismo, de modo geral, desempenhava para a filosofia estoica três funções básicas: ${ }^{10}$

1. Função ideológica de transfigurar o império existente e seu imperador.

2. Função filosófica prática de conduzir o padecente ser humano individual ao discernimento salvífico e descentralizante de ter parte numa ordem racional abrangente -, mas isso funciona apenas com um reduzido número de pessoas altamente educadas que podem participar da vida do espírito (bios theoreticos), como bem objetou Agostinho em De Civitate Dei.

3. Função lógica e ontológica de finalizar a representação teórica da ordem racional da existência, que teve os efeitos históricos mais decisivos, acelerando o desenvolvimento da deliberação ética universal desde pelo menos a gênese do cristianismo (Kleingeld, 2006), para então produzir, posteriormente, alguns efeitos políticos e jurídicos bastante concretos.

Para além disso, o cosmopolitismo clássico não teve qualquer importância direta em termos jurídicos ou políticos e, diferentemente dos pretensos hábitos antipolíticos dos cristãos, ${ }^{11}$ a maioria dos filósofos cosmopolitas pagãos estavam profundamente de acordo com a estrutura básica da dominação de classe no seio do mundo político vigente em suas repúblicas e impérios. Os cristãos eram diferentes porque (1) seu império não era deste mundo, mas de um mundo de natureza diversa, e (2) esse império transcendente era concebido como totalmente igualitário, o que, em princípio, permitiu que desenvolvessem uma critica radical da ordem politica vigente. No princípio, isso representava, na melhor das hipóteses, um utopismo abstrato, mas depois, a partir do século XI, foi convertido numa tensão interna que se manteve no seio da ordem política e jurídica mundial vigente. ${ }^{12}$

\section{O primeiro Estado cosmopolita e a liberdade de associação}

A Revolução Papal unificou as massas e mobilizou-as contra o alto clero, a alta nobreza e o imperador sob o lema "Liberdade diante da Igreja!" As lutas de classe intercaladas entre clero e nobreza, entre campesinos e barōes salteadores, entre servos e senhores, entre a plebe urbana, os burgueses, o baixo clero e a baixa nobreza, de um lado, e o alto clero e alta nobreza, de outro, ${ }^{13}$ levaram por fim a um processo de aprendizagem normativa ${ }^{14} \mathrm{e}$ à invenção e a corporificação institucional de uma nova ideia geral de liberdade, a primeira liberdade moderna: liberdade corporativa (Brunkhorst, 2009).

Uma ordem cosmopolita política e juridicamente significativa somente foi inventada na Eu- 
ropa ocidental após a Revolução Papal do final do século XI. A razão para a virada jurídica e política do cosmopolitismo a partir do século XII na Europa ocidental já foi destacada por Max Weber: trata-se do início da construção do Estado moderno, e o primeiro Estado moderno a emergir ao longo da Primeira Revolução Europeia (Moore) foi o Estado universal da Igreja. Weber descreveu a Igreja daquela época como a "primeira burocracia racional", uma "organização moderna", "racional”, um "exército disciplinado de poder administrativo" (primeiro Estado institucional [Anstaltsstaat]) [Weber, 1964, pp. 432, 480, 549, s. a. 615f; vgl. a. Weber, Das antike Judentum, 7].

Esse Estado se descrevia como uma ordem cosmopolita juridicamente organizada: um contínuo internamente diferenciado, que compreendia civitas dei e civitas terrena, como uma espécie de confederação universal. O poder político, a esfera religiosa e a ordem jurídica formavam um sistema constitucional completamente "juridicizado" (Fried, 1974), que viabilizou a reconciliação de opostos perenes (Berman, 2004). A reconciliação constitucional dialética entre perenes contradiçōes sociais, políticas, legais e religiosas foi repetida, reinventada, renovada e reorganizada muitas outras vezes em todas as grandes revoluções europeias.

O sistema constitucional estabelecido pela Primeira Revolução Europeia estava baseado na liberdade corporativa e abriu um caminho evolutivo para a modernidade, que levou, pela primeira vez na Europa, não apenas à coexistência das já estabelecidas corporações jurídicas, religiosas e políticas da Igreja Cristã, do Império Cristão e dos reinos cristãos, que se pretendiam, todos e cada um, "soberanos”, como também permitiu o florescimento de corporaçôes inteiramente novas e autônomas, como universidades, corporações discentes (nationes), guildas e cidades-estados republicanas completamente reorganizadas.

O conceito jurídico de uma corporação (corpus, universitas, collegium) adequava-se, na verdade, a praticamente tudo, de associações comerciais a entidades filantrópicas, passando por bispados, pela Igreja como um todo, pela totalidade do mundo cristão e por todo o corpo cósmico de Cristo. O direito canônico da corporação, pela primeira vez na história, não mais se baseia em laços de parentesco e família, mas na função, afiliação e organização formal (Weber, 1964). Para estabelecer uma nova corporação no direito canônico, bastava apenas um mínimo de três membros (Berman, 2004, p. 364; Struve, 2004). O direito canônico abolia o privilégio imperial que o velho direito romano reservava para autorizar a formação de uma corporação, outorgando a todas as corporações uma jurisdição autônoma (que se restringia, no direito romano, apenas a corporações públicas). $\mathrm{O}$ direito canônico inventou a forma jurídica moderna da personalidade associativa conjugada (Verbandspersönlichkeit), com patrimônio conjugado e responsabilidade solidária e limitada (Gesamthaftung). O velho princípio do direito civil romano da herança, segundo o qual aquilo que afeta a todos exige a anuência de todos (quod omnes similiter tangit, ab omnibus comprebetur), foi formalizado e generalizado como uma regra jurídica de organização corporativa e de tomada de decisões (Berman, 2004, p. 366; Maddox, 1996, p. 99; Landau, 1996, p. 42). Já não existia (como nos velhos direitos romano e germânico) uma personalidade do grupo que se situava além da vontade de seus membros individuais (Berman, 2004, p. 364). O direito canônico da corporação foi, como já observou Weber, pioneiro e precursor da transformação da gestão política numa "moderna administração estatal institucionalizada" (moderne anstaltsmäßige Staatsverwaltung) (Weber, 1964, p. 549, s. a. 615f).

A ideia de uma Igreja universal, ou Ecclesia Universalis (Moore, 2001 , pp. 72, 189f, 225; Wieacker, 1967; Schatz, 1990, p. 107, vg. a. 103; Cantor, 1969, p. 228, 273f; Berman, 2004; Brundage, 1995), ${ }^{15}$ era mais do que mera ideologia. Tratava-se do que Hegel chamava de ideia vigente, pois a base estrutural do Estado cosmopolita jurídico consistia na plena diferenciação funcional do direito, que já não mais formava uma ordem jurídica, mas pela primeira vez um sistema jurídico, com uma organização internamente diferenciada, com tribunais em seu núcleo e uma carreira jurídica para profissionais academicamente treinados que asseguravam a autonomia do sistema (Berman, 2004, 2005; Luhmann, $1997 \mathrm{a}$ e b). O nascimento do direito moderno e do moderno sistema de universidades foi 
co-original. A partir de então, o sistema jurídico já não podia ser dirigido de fora do sistema. Poderia ser até destruído, mas nunca mais controlado.

O direito dos canonistas já não era um mero direito cooperativo, utilizado para transações entre membros das classes dominantes do Império, como havia sido o caso do antigo direito romano. O direito canônico não era somente a base de um sistema social autônomo luhmaniano, como um "sistema de imunidade" da sociedade, com a única função de "estabilizar expectativas recíprocas" (Luhmann, 1997a e b) -, era também e simultaneamente um instrumento jurídico destinado a modificar e a reformar o mundo rumo à emancipação universal e à salvação. Pela primeira vez, a recepção do direito romano seguia junto com o discurso ético cosmopolita da gênese do cristianismo. Mas o sistema de poder clerical juridicizado sobre corpo e alma das pessoas atuava muito melhor e era muito mais eficaz que o controle romano, exercido por coerção externa e administração mais bem ordenada (Strayer, 1970, 1956; Moore, 2001).

As consequências são de duas ordens: o discurso ético cosmopolita do amor fraternal universal perdeu seu caráter abstrato e utópico, pois agora estava encarnado num sistema jurídico, e produziu consequências e efeitos jurídicos concretos (Rechtsfolgen) - para bem $e$ para mal (por exemplo, a tortura processual, o controle disciplinador, o poder pastoral, a eficiente exploração da população rural). Por outro lado, o direito romano já não era mero instrumento imperial de controle de classe, um direito apenas de coordenação e repressão, mas, pela primeira vez, uma instância da liberdade (Dasein der Freiheit), "um sistema destinado a realizar a liberdade” (Hegel, 1970, p. 46). ${ }^{16}$

\section{Liberdade do ser humano individual}

A tensão entre a função repressiva e o compromisso emancipatório do primeiro sistema jurídico moderno foi alterada pela subsequente grande transformação revolucionária da Europa, a Revolução Protestante, numa contradição claramente articulada pelo levante campesino de 1525 . A revolução tinha seu centro na Alemanha do século XVI, nos Países Baixos dos século XVI e XVII e no Reino
Unido do século XVII, mas modificou todo o mundo europeu (incluindo a Igreja Católica e os reinos católicos). O processo de aprendizado normativo da Revolução Protestante foi orientado pela nova ideia da liberdade do fiel cristão individual, e uma de suas facçôes mais radicais, os camponeses do sul da Alemanha do levante de 1525 , já havia formulado essa liberdade pela primeira vez como um moderno direito humano de liberdade. Nos Doze Artigos de Memmingen, o artigo $3^{\mathrm{o}}$, sentença $2^{\mathrm{a}}$, estipula "que nós (como homens ou criaçôes do Deus universal [n.a.]) somos e que nós queremos ser livres".

Os camponeses lutaram pela liberdade (Leibeigenschaft) e contra a ordem então vigente que instituía a servidão. Mas foi em nome dessa ordem jurídica que eles e seus líderes intelectuais e conselheiros legais insistiram na validade daquele direito canônico que, diferentemente do particularista e repressivo direito civil, proibia seus mestres de restringir seus direitos ao matrimônio livre em seu próprio domínio regional. Articularam aquela contradição entre direito canônico e civil, que só então se tornou óbvia como tal. Ademais, os camponeses utilizavam-se do ius commune do Schwabenspiegel ${ }^{17}$ para opor suas passagens universais, que (com base na Bíblia) refutavam categoricamente a servidão, às suas passagens particularistas, que a validavam sob certas condições históricas. Seu célebre lema revolucionário, a questão retórica "Onde estava o nobre enquanto Adão cavava e Eva fiava?” (Als Adam grub und Eva spann, wo war denn da der Edelmann?), remete diretamente às fontes legais do Espelho dos Suábios e do Espelho dos Saxôes (Blickle, 2003).

\section{Coevolução das estatalidades universal e nacional}

Nos séculos XII e XII, pela primeira vez na história, as velhas ideias cosmopolitas foram corporificadas num grandioso experimento social, o que produziu consideráveis efeitos históricos. $\mathrm{O}$ mais importante foi que, desde o princípio mais longínquo da sociedade moderna na Europa, as estatalidades universal e plural emergiram coevolutivamente. Isso foi ativado pelo Estado jurídico universal da Igreja, mas, pouco tempo depois, os reinos europeus começaram a emular as invenções administrativas e jurídicas do direito canônico (Strayer, 1970, 
p. 22). Tanto o Estado universal da Igreja, como os poderosos reinos, o Império e as cidades-estados republicanas estavam todos integrados socialmente por um tipo de direito constitucional universal. ${ }^{18}$ Distintamente da leitura consagrada a respeito da emergência do Estado moderno, que a atribui unicamente ao absolutismo e ao protestantismo, seria possível buscar, a partir do século XVI, com base em estudos como os de Berman, Moore, Brundage, Strayer, Tierney e outros, ${ }^{19}$ uma tese alternativa, segundo a qual o Estado moderno emergiu da co-originalidade do Estado cosmopolita ou universal e do Estado territorial, que muito mais tarde viria a ser o Estado nacional moderno.

Depois que a Revolução Protestante destruiu o Estado cosmopolita da Igreja, substituindo-o pelo sistema europeu de Estados territoriais e moldando, ao longo dos séculos XVII e XVIII, o que se tornaria o moderno Estado nacional, a ordem cosmopolita não desapareceu inteiramente, mas foi reconstruída como um novo tipo de ius gentium. Foi este direito transnacional, e não o direito nacional ou estatal, que fundou a ordem europeia de Estados por meio do direito dos tratados, que (desde a paz revolucionária de Augsburgo, em 1555, apenas repetida e confirmada pela menos importante Pax Westfalia) garantiu não só a soberania igualitária de todas as monarquias europeias e seu direito a escolher entre pelo menos duas religiōes cristãs (cuius regio, eius religio), mas também o novo direito subjetivo de apostasia, ao menos para um pequeno número de homens proprietários e chefes de família, que gozavam dessa liberdade privilegiada. Mas desde a emergência das modernas constituições democráticas no século XVIII, e essa é minha segunda tese, o cosmopolitismo está de volta e, pela primeira vez, é democrático.

\section{Avanços revolucionários}

Uma ordem jurídica que combina o direito básico cosmopolita universal com regras procedimentais concretas, direitos subjetivos com ritos judiciais, legislativos e administrativos (ver seção "O primeiro Estado cosmopolita e a liberdade de associação" a seção "Coevolução das estatalidades universal e nacional", define-se, de saída, como uma ordem dinâmica que transcende a si mesma. Isso é verdade ao menos para todas as constituições a um só tempo revolucionárias e democráticas. ${ }^{20}$ É próprio do fulcro da Declaração de Independência e da Constituição dos Estados Unidos combinar direito dinâmico de revisão judicial, normas procedimentais de controle federativo e funcional e limitações recíprocas, por meio da invocação da liberdade igualitária de todos os homens e do direito universal de todos os povos à autodeterminação. ${ }^{21}$ Desde o início, essas invenções jurídicas fundamentais fomentaram o experimentalismo e o expansionismo democrático (John Dewey), para bem ou para mal.

Elas levaram ao dinamismo imperial da fronteira aberta para o Oeste, com o florescimento da democracia camponesa (como retratado em $O$ homem que matou o facinora, de John Ford) (Brunkhorst e Koch, 2005), e à virtual extinção da população aborígene da América do Norte: "Pare de chamar de agressão/ Odiamos essa expressão!/ Só queremos que o mundo saiba/ Que aprovamos o status quol Somos amados aonde quer que vamos/ Portanto, na dúvida,/ Mandem os fuzileiros!”. ${ }^{22}$

Levaram à antimonarquista Doutrina Monroe de um lado, uma iniciativa em defesa do progresso universal da democracia contra as pretensões da Santa Aliança europeia, mas, de outro, um documento que lançou as bases do império e do imperialismo norte-americano. "Pois o forte faz o justo/ E enquanto não virem a luz/ Eles têm de ser protegidos/ Todos os seus direitos assegurados/ Até que alguém de quem gostamos seja eleito".

Levaram ao discurso de Gettysburg, que combinava a liberdade igualitária de todos os homens ("que todos os homens são criados iguais") - a verdade patente da Declaração de Independência interpretada por Lincoln, pela primeira vez na história americana, como ius cogens - com uma demanda universal pelo autogoverno democrático: "que a democracia não desapareça da Terra”.

Levaram à revisão das duas guerras mundiais como guerras revolucionárias, travadas para "tornar o mundo seguro para a democracia" (Wilson) e para assegurar a "igualdade na busca pela liberdade" para os cidadãos "de todas as naçōes" (Franklin D. Roosevelt); no entanto, ao mesmo tempo, foram usadas 
para legitimar aspiraçóes imperiais das Forças Armadas dos Estados Unidos em todo o mundo.

Levaram à ampla extensão de direitos operada por meio do New Deal, à Carta do Atlântico, ao assistencialismo internacional, à fundação das Nações Unidas, à Declaração Universal dos Direitos Humanos e à iniciativa global para a introdução de um novo direito internacional e para a implementação de regimes de direitos humanos em todo o mundo (seção "Uma nova ideia de liberdade", adiante). Porém, ao mesmo tempo, livrou os Estados Unidos, repetidas vezes, da submissão à vigência do direito internacional - e sempre com o mesmo argumento, segundo o qual é "nossa" constituição democrática que "nos" impede de tornar um rol de direitos humanos internacionais a "lei suprema da nação" (art. VI da Constituição dos Estados Unidos), seja ratificando-o por um ato do Congresso ou citando-o numa decisão da Suprema Corte (Byers, 2003). ${ }^{23}$ "Quando quer que alguém se mexa/ De um jeito que não aprovamos/ Quem é que sempre intervém? ONU e OEA/ Têm seu lugar, eu acho,/ Mas, antes, mandem os fuzileiros!”.

Levaram à transformação, a partir da década de 1960, dos direitos iguais em normas antidiscriminatórias, que tiveram um forte impacto global; mas, ao mesmo tempo, a revolução dos direitos não foi capaz de impedir a crescente exclusão de uma subclasse em dramática expansão, para a qual normas antidiscriminatórias desacompanhadas de assistência médica, educação básica etc. eram liberdades sem qualquer valor real, para não mencionar as leis imigratórias e a exclusão da periferia global.

Há um claro vínculo intrínseco entre o universalismo democrático e os fuzileiros, vínculo que conduz das demandas juridicas universais a novas formas de exploração e dominação opressivas, como observou Karl Marx tão precoce quanto acertadamente a respeito do exemplo da Revolução Francesa (Marx, 1966, 1851). Num regime constitucional hegemônico de proprietários brancos, a provisão legal (Gesetzesvorbehalt) normalmente se converte num provimento de classe (raça ou gênero) e, uma vez que se tenha tornado a interpretação válida da constituição, são necessários movimentos emancipatórios, organizações fortes e tenazes e, não raro, confrontos sociais revolucionários, por vezes mesmo guerras civis, para alterá-la. Contudo, justamente porque o expansionismo democrático não apenas é definido em termos geopolíticos (por exemplo, pelas ideologias do continentalismo ou do globalismo), mas também se relaciona com todas as dimensões de nosso mundo da vida, de nossa terrenidade ou existência-no-mundo (Lebenswelt, In-der-Welt-Sein), é que não pode ser meramente reduzido a imperialismo opressivo (ver Brunkhorst, 1998). Que existam ligações entre o universalismo democrático e os fuzileiros, entre a Declaração dos Direitos do Homem e do Cidadão e o Império Napoleônico não implica dizer que sejam a mesma coisa ou tão somente dois lados de uma mesma moeda. Sugerir uma imutabilidade entre essência (material) e aparência (ideal), entre os direitos universais e impérios universais, como sempre fizeram os marxistas ortodoxos, não é mais que uma recaída na metafísica dualista. Há sempre um contínuo de práticas em meio ao qual podemos traçar uma série de distinções, e é apenas nos dois polos que teremos casos idealmente puros. $\mathrm{O}$ expansionismo democrático constitucionalmente articulado não é apenas uma arma ideológica e jurídica nas mãos de latifundiários opressores, capitalistas exploradores e governos imperiais, mas também segue sendo - simultaneamente - uma arma por vezes bastante efetiva que pode ser utilizada para desbancá-los. Com efeito, existe uma diferença crucial entre continentalismo geopolítico e expansionismo socialmente inclusivo, assim como entre globalização geopolítica e mundialização abrangente, ainda que sejam por vezes confundidos, tanto na teoria como na prática.

A mesma dinâmica da "estrutura reflexiva de autolegislação” (Bruns-Schmalz, 2010) pode ser observada na história do direito constitucional francês desde 1789. Observou-se com frequência que houve uma emancipação imediata em relação a regimes opressivos e despóticos, assim como a fundação de novas repúblicas nos países vizinhos da França, a europeização do Código Civil como a "lei da liberdade" (Hegel) e a emancipação dos escravos nas colônias francesas. Contudo, ao mesmo tempo, houve a restauração da escravidão, do sanguinário imperialismo francês, a europeização do estado de sítio, que Marx ironicamente caracterizou como uma “oportuna invenção da Revolução Francesa, 
[que] libertou inteiramente a sociedade civil do incômodo de governar-se a si mesma”. ${ }^{24}$

O mais importante e avançado dentre os artigos da famosa Declaração francesa de agosto de 1789, o artigo 16, implicitamente declara guerra a todos os regimes que não possuem constituição democrática, ao afirmar que "uma sociedade na qual a obediência à lei não está assegurada, nem tampouco a separação dos poderes definida, não possui constituição alguma". ${ }^{25}$

Por causa da combinação dinâmica entre direitos universais e normas procedimentais de auto-organização, todas as implicaçõos cosmopolitas são intrínsecas a todas as constituiçõos democráticas e, por exemplo, os artigos 23 (1), 24 (1) e 25 da Lei Fundamental Alemã de 1948 são meros passos ulteriores que levam todos na mesma direção da autotranscendência democrática cosmopolita. ${ }^{26}$

O sentido e o uso que Rousseau, Sieyès, Kant e seus contemporâneos já haviam feito de locuções tão populares como soberania popular ou poder constituinte não eram (como insinuou Schmitt em sua Doutrina Constitucional) substantivas ou normativas. O vocabulário da "soberania popular", "direitos" e "constituição" foi inicialmente de uso prático e profundamente necessário para delinear instituiçôes democráticas, para emancipar-nos da dominação e da opressão, para criticar governantes que se consideravam "príncipes soberanos", "autocratas soberanos", divinamente "eleitos" ou "verdadeiros" representantes de seu povo e para remover um maquinário estatal que se encontrava inteiramente alienado de seus cidadãos e não sob seu controle. A ideia da legalidade democrática, do estado de direito, ao longo do final do século XVIII e na teoria constitucional democrática (como na celebrada teoria do direito de Kelsen), não significava Rechtstaat, que associa o direito ao Estado e não ao povo, mas rule of law, que vincula o Estado à vontade popular (ver Brunkhorst, 2000).

\section{Uma nova ideia de liberdade}

Mesmo que a ideia normativa de um poder constituinte e a integração constitucional da soberania popular com os direitos humanos a partir do final do século XVIII tenham sido inerentemente cosmopolitas e tenham tido (e ainda tenham) implicações tanto cosmopolitas como imperiais, o cosmopolitismo do século XX já não é o mesmo da época em que Kant escreveu seu ensaio sobre a Paz Perpétua.

Há claras e sólidas continuidades, o texto da Constituição Americana ainda é o mesmo que há 250 anos, tendo sido emendado apenas algumas vezes, mas a constituição não é mais a mesma (Ackerman, 1998). A mais recente constituição francesa preserva ainda a formulação da Declaração de 1789, mas o novo direito constitucional mudou profundamente seu sentido. Essas descontinuidades foram causadas pelos conflitos sociais e políticos e pelas guerras, revoluções e catástrofes do século XIX e, em especial, por aqueles que ocorreram durante a primeira metade do século XX.

Desde o fim da Segunda Guerra Mundial, assistimos a um processo impressionantemente rápido e abrangente de juridicização e constitucionalização global. ${ }^{27}$ Aquilo que ocorreu durante os dez anos entre 1941 e 1951, entre a Carta Atlântica e a fundação da primeira Comunidade Europeia, não foi somente evolução jurídica como de costume, mas uma considerável mudança revolucionária. ${ }^{28}$

A profunda e alentada transformação social que alcançou seu auge em meados do século XX foi precedida por mais de cem anos de movimento operário e de outros importantes movimentos sociais - especialmente, o feminista - e por numerosos movimentos pacifistas de grande expressão. Estes surgiram ao mesmo tempo que o movimento operário e suas poderosas organizações e, no mais das vezes, estreitamente associados a eles (cf. Vester, 1970; Hobsbawm, 1987, caps. 5, 8 e 12; Sassoon, 1996, vol. 1). Essa transformação foi precedida por incontáveis levantes, pela Revolução Russa e por diversas revoluçóes e guerras civis de menor envergadura, além das - por último, mas certamente não de menos importância - duas guerras mundiais. Ao longo dos cinquenta anos entre 1892 e 1941, Charles Tilly enumera 65 situações revolucionárias somente na Europa. Numa perspectiva mais ampla, desde a virada de 1691, o único período de mudança capaz de eclipsar essa transformação são os cinquenta anos que se seguiram à Revolução Francesa 
(Tilly, 1995, p. 243). Ambas as guerras mundiais foram encerradas não com o tradicional tratado de paz, mas com a criação de um novo direito internacional, com amplas mudanças constitucionais numa série de regimes nacionais e com uma "remodelagem epocal do sistema de Estados" (Maul, 2010) e com a fundação de confederações globais e regionais de Estados e povos. ${ }^{29}$ Aquilo que se dizia da Europa após a Revolução Francesa não era muito diferente: um mapa inteiramente novo (sistema de estados), novos direitos nacional e internacional, novos regimes constitucionais e, não se deve esquecer, novas confederações etc.

O Tratado de Versalhes, que encerrou a Primeira Guerra Mundial, foi historicamente singular porque, por seu intermédio, pela primeira vez na história moderna, (1) a individualização do direito internacional foi estipulada (artigos 227-230), ${ }^{30}$ (2) foi fundada a Liga das Naçóes e promulgado seu Pacto (artigos 1-26), e (3) o Tratado constituiu formalmente a lei do Pacto como lei suprema ${ }^{31}$ (artigo 20). ${ }^{32}$ A Segunda Guerra Mundial terminou sem qualquer acordo de paz. Foi encerrada com a rendição incondicional do Japão e da Alemanha e com o desmantelamento de seus regimes políticos autoritários. Assim, Kelsen argumentou que já não havia um Estado alemão após 1945 e que a unidade política como um todo teria de ser refundada.

A rendição incondicional foi imediatamente sucedida pela invenção dos Tribunais Militares Internacionais de Nuremberg e Tóquio, que transformaram profundamente o direito penal internacional, abriram os portóes para futuros avanços da justiça criminal internacional e ajudaram a dar forma aos dois grandes avanços posteriores nessa matéria, os subsequentes Tribunais Penais Internacional para Ruanda e para a antiga Iugoslávia e o estabelecimento da Corte Penal Internacional (CPI), que até o presente têm jurisdição (ainda restrita) para casos de violação do art. 2 IV da Carta da ONU ("ameaça de uso de força contra a integridade territorial ou a independência política de qualquer Estado-membro"). A CPI, assim como os casos Kadi e Yusuf, decididos recentemente por ambas as cortes europeias, ${ }^{33}$ são bons exemplos de passos adicionais que fazem avançar o processo de constitucionalização evolucionária da comunidade internacional, um processo iniciado nos anos $1940 .^{34}$

\section{Constitucionalização revolucionária e evolucionária}

Não obstante, como em todas transformações revolucionárias da sociedade, constitucionalismo evolucionário e revolucionário normalmente estão entrelaçados. ${ }^{35}$ Um não existe sem o outro. A Revolução Americana produziu códigos constitucionais com um espectro aberto de sentidos possíveis, que foi subsequentemente fechado e alterado repetidas vezes num longo processo de constitucionalização legislativa e jurisdicional. As constituições revolucionárias francesas foram acompanhadas por um período mais ou menos longo de relutante constitucionalismo evolucionário em toda a Europa, em parte por uma constitucionalização formal das monarquias vigentes (ou eventualmente inventadas), em parte por processos de juridicização e reformas legais. ${ }^{36}$

Um processo similar ocorreu no rastro das enormes mudanças constitucionais e jurídicas que se seguiram à Segunda Guerra Mundial. Assim como ocorre com todas as grandes reformas revolucionárias da história, mudanças nesse sentido são causadas pelo entrelaçamento de lutas de classe e processos de aprendizado coletivo (Eder, 1983). Nas sociedades modernas, as lutas de classe orientam-se normalmente pelo capital, pelo Estado ou por ambos (Tilly, 1985, p. 36) e, ademais, na maioria dos casos, orientam-se ainda por conflitos jurídicos e divisões religiosas (e "ideológicas") (Berman, 1983a). Nas revoluçôes, as novas ideias capazes de definir o curso dos eventos são a força motriz da manifestação prática dos interesses coletivos (Weber, 1978, p. 252; ver também Moore, 2001).

Para o sentido que procurarei imprimir a meu argumento final, é importante salientar que constitucionalismos revolucionário e evolucionário podem tomar caminhos diferentes. $\mathrm{O}$ processo de aprendizado normativo que se institucionalizou paradigmaticamente nas constituições revolucionárias abre e revela uma grande variedade de novos avanços evolucionários possíveis, ao mesmo tempo em que limita ou exclui outros possíveis avanços, mas 
apenas o processo evolucionário de constitucionalização e concretização legal que é conquistado em lutas de classe efetivamente em curso (constitucionalmente enquadradas, porém) é capaz de determinar quais dos novos caminhos possiveis que chegaram a ser abertos será trilhado pelo curso evolutivo, e essas podem ser trilhas muitas vezes encaradas pelos respectivos povos como uma traição das principais promessas da revolução. Por exemplo, durante a Revolução Papal, a liberdade da Igreja implicou o tempo todo a libertação dos camponeses diante de seus opressores e senhores. Mas. depois da revolução, a dominação e a exploração dos camponeses era ainda mais efetiva do que jamais havia sido, e o regime constitucional revolucionário, junto a outros, revelou essa possibilidade evolucionária que havia sido viabilizada pelas conquistas revolucionárias na direção do estado de direito. Essa trilha pôde ser seguida porque uma contingente constelação histórica de interesses coletivos a favoreceu: ${ }^{37}$ todas as principais classes dirigentes da época, a nova classe clerical, assim como a nova classe de artesãos, burgueses e magistrados das cidades florescentes, e a antiga, mas completamente reorganizada classe da aristocracia terratenente, todas possuíam o mesmo interesse material em um alto excedente da produção agrícola. Portanto, após a revolução, os camponeses perderam todos os seus potenciais aliados, sendo que a exploração e a opressão (doravante legalizadas) aumentaram ainda mais. ${ }^{38}$ Mas, como sabemos, essa não foi a única trilha evolucionária que o processo de aprendizado normativo da revolução revelou. Novas constelações de classe puderam modificá-la, finalmente, por meio de um ulterior processo de aprendizado revolucionário (ver seção "Liberdade do ser humano individual").

\section{Constitucionalização revolucionária}

Em 1945, o ato jurídico mais importante na verdade, um dos momentos constitutivos - do constitucionalismo revolucionário foi a fundação das Naçôes Unidas, cercada por uma verdadeira rede de novas instituições internacionais e complementada pela normativamente singular e revolucionária Declaração Universal dos Direitos $\mathrm{Hu}$ manos. A Carta da ONU:
1. Substituiu a figura das partes de um contrato pela adesão como membros em uma organização internacional, à qual não membros podem se candidatar (art. 4 II da Carta). ${ }^{39}$

2. Substituiu a soberania igualitária dos "príncipes soberanos e cidades livres” da Europa (Preâmbulo do Protocolo Final da Conferência Ministerial de Viena e art. 1 da Carta), conforme figurava na ordem jurídica internacional da Westfália (do século XVI ao final do século XVIII) e de Viena (século XIX e início do século XX), pelo princípio da igualdade soberana de todos os membros das Nações Unidas (art. 2 I da Carta). Como princípio jurídico, a soberania não existia previamente à Carta, tendo sido criado pela Carta (e isso é muito distinto do regime regido pelo Protocolo de Viena, no qual os príncipes soberanos figuravam como os criadores da lei, capazes de outorgá-la ou revogá-la). A soberania criada pela Carta é uma incumbência legal, o que significa que, como todas as incumbências legais, é exercida no limite da lei e no quadro de um sistema (ainda pré-democrático) de limitações recíprocas (Fassbender, 1998, pp. 94-101; Allot, 1990, pp. 173-174, 178). Na passagem da soberania igualitária para a igualdade soberana, o termo "soberania" é relegado "à posição de uma atribuição adjetiva, meramente modificando o substantivo "igualdade". Nessa combinação, pretende-se que a soberania exclua a superioridade jurídica de qualquer Estado sobre outro, mas não prevê um papel adicional a ser desempenhado pela comunidade internacional diante de seus membros (Fassbender, 1998, p. 111). Especialmente no contexto do colonialismo e do imperialismo europeus modernos, o construto da superioridade havia sido crucial pelo menos desde o Tratado de Tordesilhas, de 1494 (e uma das últimas teorias jurídicas que tentaram, sem sucesso, justificá-la foi a doutrina do espaço ampliado [Grossraumlehre], postulada por Carl Schmitt no final da década de 1930).

3. Substituiu o princípio jurídico internacional da coexistência pelos princípios universais da cooperação e das relaçôes amistosas (art. 1 I \& III). Essa virada é comparável com o abandono 
por Rousseau do antigo princípio democrático da vontade de todos para o princípio democrático moderno da vontade geral. O sujeito de direito da regra universal da cooperação já não é o Estado, mas a comunidade internacional como um todo. À luz do princípio cooperativo, o direito internacional completou a passagem de direito relacional a direito institucional (René Jean Dupuy) (Idem, p. 112).

4. Substituiu a base constitutiva unidimensional, composta unicamente pelos governos dos Estados-membros, por uma base constitutiva bidimensional, composta pelos governos dos Estados-membros e pelos "povos em cujo nome atuam tais governos" (Idem, p. 101). Ademais, a referência aos direitos humanos de cada ser humano individual (art. 1 III, combinado com os arts. 12 I, 75 c e 76 c, com a Declaração Universal, apesar de não vinculante, e com a Declaração de Relações Amistosas da Assembleia Geral de 1970) poderia até mesmo ser interpretada como uma terceira dimensão da base constitutiva, que remete a uma incipiente cidadania mundial (mesmo que tudo isso ainda esteja muito longe de um princípio de dupla legitimidade, como o que foi estabelecido pela União Europeia).

5. Estendeu a todos os Estados a proscrição da "ameaça de ou recurso ao uso da força", anteriormente válida apenas para os Estados signatários (art. 2 IV) e, ao menos nesse aspecto, constituiu já de saída a base de uma ordem jurídica universal.

\section{Constitucionalização evolucionária}

A constitucionalização evolucionária do direito e da política mundiais, que se seguiu às transformaçôes institucionais revolucionárias, abarcou, entre outros, os seguintes processos:

1. A juridicização de territórios, populações ou esferas funcionais nos níveis nacional, regional e global, assim como o crescimento orgânico do direito aplicado a esferas específicas e entre esferas - incluindo fragmentação, mas também coordenação e acomodação. ${ }^{40}$
2. A emergência de um sistema de cortes internacionais (novamente, com crescente fragmentação e, ao mesmo tempo, mecanismos jurídicos de coordenação (Bogdandy e Venzke, 2009; Halberstam, 2010).

3. A elaboração do construto jurídico dos poderes implícitos de um documento legal, tal como um tratado internacional ou a Carta da ONU (Krysztof, 1989).

4. A existência, o desenvolvimento e a construção de uma certa hierarquia normativa (Peters, 2006), e uma forma de norma fundamental (Grundnorm), tal como o princípio da inviolabilidade dos tratados (pacta sunt servanda, como fora o caso da norma fundamental que sustentou o sistema da Westfália de direito público europeu), ou ainda, uma norma superior de regulação de conflitos (norma de colisão) (Joerges, Teubner e Sand, 2007) ou de acomodação recíproca e cooperação (Halberstam, 2010), revestida de um caráter pós-convencional (Habermas, 1976a) ${ }^{41}$ ou mesmo não convencional (Ackerman, 1998).

5. O desenvolvimento de princípios constitucionais, de normas jurídicas cogentes e obrigações erga omnes (Verdross, 1971, pp. 20-21; Fassbender, 2009, pp. 43-44, 123-128).

6. Uma forte tendência na direção do direito universal (Fassbender, 2009, p. 29).

7. A emergência de uma ordem pública comum de alcance mundial (ordem pública internacional) (Idem, pp. 27ss; Fischer-Lescano, 2005).

8. A gradual adaptação (e substituição parcial) de medidas isoladas tomadas pelo Conselho de Segurança das Nações Unidas por um procedimento legislativo geral, especialmente em decisões relativas a embargos adotados como medida punitiva dirigida unicamente contra o Estado, mas também considerando medidas jurídicas gerais voltadas a todos os seus potenciais parceiros econômicos. Com base no art. 39 da Carta, o Conselho de Segurança pode "decretar a ilegalidade de certas atividades incompatíveis com os interesses fundamentais da comunidade internacional", relacionadas, por exemplo, com a regulação de armas de destruição em massa ou com a proteção do meio 
ambiente global (Tomuschat, 1993, p. 344; Fassbender, 2009, pp. 95-96). Em especial, as resoluçôes contra o terrorismo têm cada vez mais assumido o caráter de obrigaçôes gerais e abstratas (e isso tem-se confirmado, por exemplo, pelas sentenças das cortes europeias relativas ao caso Kadi (Fassbender, 2009, p. 96).

9. A autovinculação dos Estados foi emendada por uma lei suprema de alcance global na esfera do direito público internacional (Idem, pp. 3154, 103).

\section{Dignidade igualitária e democracia social de massa}

A Carta, o novo direito internacional e o processo de constitucionalização foram o resultado de revoluçōes e guerras mundiais do século XX, travadas não apenas em nome do interesse nacional ou do interesse de uma classe específica, mas também em vista de metas e normas universais, pela democracia, pelos direitos humanos e pelo socialismo (Marks, 2000). O presidente dos Estados Unidos, Woodrow Wilson, em 1917, conclama uma "guerra para cessar todas as guerras", refletindo claramente o grito de guerra dos movimentos e revoluções socialistas: "Encaremos a última batalha/ A Internacional conquista os direitos humanos". ${ }^{42}$ A Constituição da República Federal Socialista Soviética da Rússia, de dezembro de 1918, seguiu a trajetória apontada na Paz Eterna de Kant, empregando praticamente os mesmos termos que Wilson utilizara em seus 14 Pontos, de janeiro de 1918, e antecipando a Carta Atlântica de Roosevelt e Churchill e a muito mais tardia terminologia da propaganda norte-americana em torno da paz democrática, que declarava a "revogação de todos os tratados secretos" e a "realização de todos os esforços conducentes a uma paz democrática geral, sem anexaçōes ou reparações, sobre a base da livre determinação dos povos" (art. 1, cap. III 4).

A dimensão internacional teve um papel constitutivo não somente para a paz mundial, mas também para a liberdade política e reformas sociais revolucionárias. Desde o início, o desenvolvimento dos estados de bem-estar social resultou da inter-relação transfronteiriça entre demandas nacionais e internacionais. A Organização Internacional do Trabalho
(OIT) já havia sido fundada em 1919, um ano após a primeira Constituição da Rússia Soviética, que contemplava um rol rudimentar de normas antidiscriminatórias e programas de ação afirmativa, além de declarar solidariedade internacional com as "centenas de milhōes de escravizados em meio à população trabalhadora da Ásia, das colônias e dos países pequenos em geral", ${ }^{43}$ enquanto, no mesmo ano, a Constituição Alemã republicana e democrática promulgava o primeiro rol abrangente de garantias sociais previdenciárias. $\mathrm{O}$ internacionalismo previdenciário não era somente um antigo projeto do movimento operário (fundamental, mas não exclusivamente organizado sobre bases nacionais), mas foi também o fundamento sobre o qual se estabeleceram as bases dos sistemas previdenciários nacionais na reconstrução posterior à Segunda Guerra Mundial (Leisering, 2007, p. 200). Emergiu não apenas de fontes socialistas, mas também de fontes republicanas e jacobinas. Na França, "desde o final do século XIX (e sob a influência da sociologia e do cientificismo da escola durkheimiana), o igualitarismo político foi ampliado ao ponto de se tornar uma noção abrangente de solidariedade social, que logo se popularizou e, já de saída, esteve estreitamente associado à ideia de uma Liga de Nações" (Grimm, 1973, pp. 38ss.; Wüst, 2007, n. 412).

Um dos principais pontos de virada da política colonial foi a Declaração da Filadélfia (Anexo da Constituição da OIT) ${ }^{44}$ de 1944 , que, pela primeira vez na história, começou a desenvolver o conceito de direitos sociais universais do indivíduo (Anexos II e III) em um documento legal que declarava serem tais direitos "integralmente aplicáveis a todos os povos em todos os lugares" (Anexo V). Os Estados e as organizaçóes internacionais se comprometiam com o estabelecimento universal de estados de bem-estar (Anexos II a e b e IV). Merece destaque o princípio da liberdade de associação (Preâmbulo da Constituição, Anexo I b e III e), que não somente precedeu a Convenção da Liberdade de Associação e Proteção do Direito a se Organizar, de 1948, mas também criou as bases para uma ruptura completa com o antigo sistema colonial de apartheid global, trabalho forçado e compulsório (Anexos $\mathrm{I}$ a e $\mathrm{b}$ e III $\mathrm{b}$ e c) e leis discriminatórias (Anexo II a), que eram constitutivos do colonialismo e do 
imperialismo europeus até 1945. Até então, o infame artigo 35 da Conferência de Berlim sobre o futuro da África (1884-1885) continuava válido: a “jurisdição" para as nações civilizadas da Europa, "autoridade" para aquelas encravadas no coração das trevas (Koskenniemi, 2001, p. 126). Esse "passo revolucionário" de refundação de fato da OIT sobre a base da Declaração da Filadélfia ofereceu ao "movimento anticolonialista do pós-guerra uma ferramenta efetiva para revelar as contradiçôes inerentes à pretensão das potências coloniais ao domínio e para formular suas próprias demandas por participação e emancipação" (Maul, 2010). A Declaração da OIT comprometia-se não apenas com o desenvolvimento, mas também com a "conquista" do "autogoverno" (Anexo V).

Para o sucesso final dos movimentos revolucionários anticoloniais contra as antigas potências coloniais - Grã-Bretanha, França e Bélgica - na década de 1960, um dos marcos fundamentais foi a vitória militar sobre as duas potências imperiais mais agressivas do mundo, o Japão e a Alemanha. Após 1995, o colonialismo já não seria capaz de obter apoio no direito internacional. A história da OIT após a Segunda Guerra Mundial é paradigmática. Já não eram apenas as decadentes potências coloniais, mas o mundo industrializado como um todo que se confrontava, pela primeira vez, com a oposição do restante da comunidade mundial, lideradas por vozes poderosas da Índia. Depois disso, os Estados industrializados perderam seus baluartes majoritários, com a emergência dos novos Estados pós-coloniais, que passaram a se tornar membros da OIT e da Assembleia Geral da ONU. Primeiro, os novos Estados absorveram as teorias da modernização do mundo industrializado ocidental (ou oriental) para, em seguida, submetê-las a um intenso ataque.

O retorno da Uniāo Soviética à OIT, em 1954, após a morte de Stalin, foi a prova da força integradora do novo arcabouço constitucional da OIT (novamente, há um claro paralelo com o desenvolvimento da Assembleia Geral da ONU). ${ }^{45} \mathrm{O}$ conflito entre a estreita maioria comandada pela União Soviética na OIT e a liderança exercida pelos Estados Unidos não chegaram a destruir a organização, mas levaram a uma série de compromissos pragmáticos e, por fim, a seu fortalecimento. Ademais, a OIT tornou-se, junto com a Assembleia Geral, um fórum para as novas frentes das lutas de classes internacionais entre o centro e a periferia globais. As organizações sindicais dos países ricos foram subitamente confrontadas com as organizações sindicais dos países pobres, que se esforçavam, sob a liderança em parte da Índia e em parte da União Soviética, para reinventar globalmente a ideia do Estado ativo, em contraposição às ideologias dos mercados livres globais. O resultado foi um "crescimento sem precedentes nas ratificações de [...] normas” que estabeleciam "padrōes de direitos humanos" relacionados com "a discriminação, o trabalho forçado e a liberdade de associação", apesar de que, ao mesmo tempo, a maior parte dos países descolonizados ainda resistia ao processo de "aplicação irrestrita" desses padrôes (Maul, 2010). A maioria dos regimes mais ou menos autoritários dos Estados que haviam sido colônias (e que, mesmo tendo lutado contra o trabalho forçado, utilizavam-no agora) vinculava-se, ao menos, a direitos e princípios genéricos que posteriormente poderiam ser, e de fato eram, utilizados contra seus próprios regimes de aplicação arbitrária e relutante. Mas o que parece ser ainda mais importante é que essa luta em torno da interpretação e da aplicação dos padrões básicos da OIT manteve a disputa "no quadro da ordem internacional" e, mesmo que uma série de novos regimes autoritários tenham procurado argumentar que se encontravam em um transitório estado de emergência, eles agora tinham de fazê-lo a partir de dentro do arcabouço constitucional da OIT (Idem). A flexibilidade da nova ordem constitucional global era não apenas uma fonte de fragmentação, de ainda mais informalização e do surgimento de uma nova dominação informal, mas também o enquadramento para uma reconciliação de longo prazo de contradiçôes perenes, e isso não é pouco entre as muitas realizaçóes dos processos de constitucionalização.

Não foram apenas os socialistas europeus, mas também os new dealers norte-americanos, que se esforçaram ao travar a Segunda Guerra Mundial em nome de direitos políticos e sociais e por sua implementação nacional e internacional. Não eram somente os socialistas radicais que possuíam uma 
retórica verdadeiramente revolucionária, o mesmo podendo ser dito a respeito dos new dealers norte-americanos. De fato, para os new dealers, como o assessor de Roosevelt, Charles Merriam, a ideia de uma "Carta de Direitos Mundial" era "revolucionária em essência - muito mais do que qualquer outra revolução mundial" e, portanto, acabaria por se tornar a "base" de todos os "movimentos revolucionários” atuais e futuros (Merriam, 1946, pp. 11ss).

Além disso, tanto para comunistas russos e socialistas europeus como para o presidente norte-americano, o "capitalista" Franklin D. Roosevelt, a revolução política, outrora almejada na busca da "liberdade diante da tirania da autocracia política", teria agora de ser suplementada por uma revolução social, alcançada na luta pela liberdade diante do "despotismo" dos "monarquistas econômicos" e da "ditadura industrial", que havia obtido (como Marx bem poderia ter dito) "o controle sobre o dinheiro dos outros, o trabalho dos outros - a vida dos outros". De um momento a outro, aquilo que havia sido negado por mais de 150 anos pelos ideólogos da sociedade burguesa se tornou verdade, isto é, que, sem o "direito ao trabalho" e "direito a viver" uma vida segura e decente, o "direito ao voto" não tinha qualquer valor para as pessoas. E quanto a isso, Roosevelt apresenta o mesmo argumento (a propósito, de velha cepa socialista) que Rawls mais tarde usaria em suas reflexões a respeito do igual valor da liberdade. Em seu discurso à Convenção $\mathrm{Na}$ cional do Partido Democrata de 1936, Roosevelt afirmou: "Diante da desigualdade econômica [...], a igualdade política carece de sentido" (Roosevelt, 1936, p 230). Não muito distante da tese básica do livro freudiano-marxista de Herbert Marcuse, Eros e civilização, publicado em 1955, Roosevelt argumentava: "Homens necessitados não são livres" (Roosevelt, 2004, p. 242; ver Merriam, 1946, p. 14). Portanto, a Segunda Carta de Direitos, de 1944, teve de alterar o direito humano fundamental da "busca da liberdade", conforme constava da Declaração de Independência dos Estados Unidos, de 1766, na "garantia" daquele adicional definido por Roosevelt, "da igualdade na busca da felicidade" (Roosevelt, 2004, p. 242). Roosevelt e os new dealers "lutavam [...] tanto pela democracia econômica como política”, sendo que alguns deles chega- ram mesmo a solicitar ao Congresso uma emenda constitucional que "estabelecesse o direito das pessoas à ter tanto a democracia industrial como política" (Rosenman, 1952, p. 264). ${ }^{46}$

Não foram, assim, somente os autores do Manifesto Comunista de 1848 que apresentaram um plano para uma revolução social que viria a se tornar uma revolução mundial. Noventa anos depois, e em reação à dupla ameaça do comunismo soviético e da maior crise econômica na história do capitalismo moderno, até mesmo o "capitalista" Roosevelt descreveu a luta contra a desigualdade econômica como uma luta "por nós mesmos e pelo mundo" (Roosevelt, 1936, p. 230). Foi somente o recurso de Roosevelt à milenar e, desde o primeiro momento, fatídica metáfora da cruzada que unificou os clamores nacionais e internacionais por uma revolução de direitos (Sunstein, 2004, pp. 73ss). Como revela claramente a metáfora da "cruzada", não existe progresso sem sua própria dialética do esclarecimento. Mesmo que não haja necessidade conceitual para tanto, projetos empiricamente imperiais e a retórica democrática dos direitos humanos com frequência seguem lado a lado (Anghie, 2004; Bhuta, 2010). É precisamente essa diferença, contudo, entre conceito e realidade, que permite às pessoas afetadas contraporem a diferença conceitual ao entrelaçamento fático entre imperialismo e direitos humanos.

Um documento importante no avanço inicial rumo à unificação entre as demandas nacionais e internacionais por uma revolução de direitos, ainda durante a Segunda Guerra Mundial, foi a Carta Atlântica, de 1941, delineada por Roosevelt e assinada pelo presidente e pelo primeiro-ministro britânico. A Carta revelava um firme compromisso com direitos econômicos e sociais: o acesso equitativo de "todos os Estados [...] ao comércio e às matérias-primas do mundo necessários para sua prosperidade econômica" (artigo 4), "a mais plena colaboração entre todas as nação no campo econômico, com o objetivo de assegurar, para todos, rigorosas normas trabalhistas, progresso econômico e segurança social (artigo 5), o estabelecimento de uma "paz que [...] oferecerá as garantias para que todas as pessoas em todos os países possam viver suas vidas livres do medo e da carência" (artigo 6). ${ }^{47}$ 
Em especial, a noção de "segurança" e a "liberdade em relação ao medo e à carência” relembram o programa do New Deal. Desde o início, quando pela primeira vez as mencionou, em janeiro de 1941, as "quatro liberdades humanas essenciais" de Roosevelt - "de expressão", "de crença", "da carência” e "do medo" - foram delineadas como direitos humanos universais (Roosevelt, 1950, p. 663).

Assim como Roosevelt vinculou a igualdade à busca da felicidade, Charles E. Merriam vinculou a igualdade de condições de vida ao direito humano básico à vida (Locke) e interpretou essa vida, à luz do pragmatismo de Dewey, como expressão e extensão de uma comunidade democrática reduzida e exclusivista (democracia burguesa) na direção de uma comunidade democrática ampla e inclusiva (democracia de massas).

O direito básico é o direito à vida - o direito ao desenvolvimento mais pleno e mais apurado das potencialidades da personalidade humana [...]. Essa é a raiz dos direitos, da qual surgem todos os outros. Os direitos civis, políticos, sociais e econômicos são implementos concebidos para efetivar o direito fundador de todos eles - a personalidade humana, com sua tenaz demanda pela expressão e pela expansão da vida, por reconhecimento da dignidade inata ao homem, pela realização das possibilidades do homem e de sua posição singular na ordem natural, social e moral (Merriam, 1946, p. 12).

Para se perseguir a realização da dignidade igualitária de todos os homens, que foi introduzida pela Declaração Universal (Artigo 1), em 1948, a cooperação institucionalizada de todas as nações é necessária. A forma assumida por esta foi o novo e cogente princípio constitucional do direito internacional estabelecido pela Carta da ONU. O primeiro artigo da Carta substituía, como vimos, o velho direito internacional da coexistência, que havia perdurado desde a Paz de Augsburgo de 1555, pelo novo direito internacional da cooperação e das relaçôes amistosas (art. 1, II-IV da Carta da ONU)..$^{48}$ Foi precisamente essa unidade entre cooperação internacional e dignidade humana que os new dealers repetidas vezes enfatizaram, argumentando que ambas as coisas deveriam ser tomadas em conjunto: a "coordenação dos direitos sociais e econômicos com os direitos políticos que os garantem e protegem", de um lado, e o "desenvolvimento de uma ordem jurídica do mundo, seguindo na direção de um governo mundial" (e não apenas a "governança”, vazia de sentido e que tão confortavelmente se adéqua à contrarrevolução neoconservadora e neoliberal dos últimos trinta anos) (Offe, 2009), de outro lado. Afinal, "nenhum sistema isoladamente é adequado, sem o concurso da família de nações na qual ele deve funcionar" (Merriam, 1946, p. 13)..$^{49}$ Após o início da Segunda Guerra Mundial, tornou-se evidente que, como descreve Merriam, "fome, doença, desemprego, insegurança, moradia inadequada, oportunidades educacionais, recreacionais e culturais insuficientes, cotas injustas de produção" eram "injustiças" às quais, "no juízo comum de gênero humano", "correspondiam direitos complementares". Essas injustiças e equívocos tornaram-se violaçôes de direitos humanos. "Medo e carência são os símbolos das injustiças contra o gênero humano que violam as reconhecidas demandas de uma humanidade compartilhada" (Idem, p. 15). Merriam reinterpreta toda a história das cartas de direitos à luz da ideia de uma igual dignidade humana como uma história de "cartas de injustiças - declarações de reivindicaçôes diante de males particulares", "protestos contra condições intoleráveis, que não podem e nem devem ser suportadas" e que são "dirigidas contra opressores de quaisquer estirpes ou contra a indiferença do orgulho e do privilégio, onde quer que se encontre e qualquer que seja o verniz de legalidade e respeitabilidade de que se revista" (Idem, ibidem).

A articulação do senso de injustiça (Barrington Moore) sempre antecede o senso de justiça (Rawls) (Moore, 1978). Como se pode ver claramente a partir do texto de Merriam, a noção de dignidade humana está estreitamente relacionada com um tipo de método dialético negativo, como na psicologia cognitiva de Piaget que se desenvolveu na Europa mais ou menos na mesma época: a descentralização inclusiva do egocentrismo normalmente começa com a "experiência da injustiça", eminentemente negativa, que viabiliza a "consciência das leis da igualdade" (Piaget, 1973, p. 311; ver 
também Brunkhorst, 1990, pp. 163ss). Esta se tornou a forma como opera a dignidade humana no contexto de regimes globais, regionais e nacionais de direitos humanos. Opera, como defendeu recentemente Habermas, não apenas como um catalisador de compromissos jurídicos (pois, sem legislação concretizadora, a dignidade humana praticamente carece de sentido, tornando-se por isso mesmo útil para gerar aceitação e apreço de partes que, de outro modo, estariam em franca oposição), mas também como um detector das mazelas das classes sociais marginalizadas e exploradas, do tratamento desigual de homens e mulheres, da discriminação de estrangeiros e de minorias sexuais, raciais, culturais elou étnicas, e por ai afora (Habermas, 2009, pp. 6ss).

A negatividade metodológica da dignidade, que generaliza o conceito, mas que $o$ abstrai de qualquer conteúdo concreto, ajusta-se precisamente à tese de Kant segundo a qual "a dignidade humana consiste" em nada mais que a "capacidade para agir como um legislador geral" em termos tanto morais como jurídicos (Kant, 1977, p. 74). ${ }^{50} \mathrm{Na}$ realidade, isso implica, como demonstrou Ingeborg Maus em sua inovadora interpretação da teoria kantiana da soberania popular, que a dignidade está intrinsecamente ligada à noção de autodeterminação (ou autolegislação) individual e coletiva (Maus, 1992). Portanto, a noção negativa de dignidade humana é somente o outro lado da moeda, social e culturalmente inclusivo, sua dimensão que demanda a "institucionalização da autonomia privada e da democracia pública" (Idem, 1990, p. 373). Isso não quer dizer que a noção de igual dignidade implique qualquer preferência por alguma forma especifica de democracia, por exemplo, pela democracia parlamentar ou pelo sistema representativo norte-americano. Ela tão somente pressupõe que os procedimentos de qualquer legislação constitucional e infraconstitucional sejam democráticos, o que implica dizer que esses procedimentos possam e devam ser aceitos como democráticos pelas próprias pessoas afetadas. Assim, qualquer conteúdo legislativo específico, qualquer arranjo institucional se deve à formação democrática da vontade daqueles que são os destinatários da lei, e somente deles (Maus, 1990, pp. 350ss, 371ss; 1992)..$^{51}$
Uma das fontes originais para o uso da dignidade na Declaração Universal pode bem haver sido uma coluna escrita por Eleanor Roosevelt no Ano Novo de 1936, que influenciou profundamente o discurso de seu marido em 1941 a respeito das quatro liberdades, assim como seu discurso de $1944 \mathrm{em}$ torno da Segunda Carta dos Direitos: "Justiça para todos, segurança em determinado padrão de vida, reconhecimento da dignidade e do direito de um ser humano individual independente de raça, credo ou cor - essas são as coisas pelas quais um vasto número de nossos cidadãos estão dispostos a se sacrificar de bom grado" (apud Goodwin, 1994, p. 201).

Ainda que, naquela época, a ação afirmativa fosse branca, ela já continha o potencial para que fosse usada pelos credos, raças e cores que ainda eram excluídos (Katznelson, 2005; McCarthy, 2009). Eleanor Roosevelt, doze anos depois, chefiou o comitê responsável por elaborar a Declaração Universal. Em especial a ênfase sobre a dignidade humana foi apoiada veementemente pela delegação francesa e por Jacques Maritain, um conservador católico tomista e defensor já célebre da "Terceira Via" europeia entre o capitalismo e o socialismo. ${ }^{52}$

Ainda assim, a influência dos new dealers sobre a Declaração Universal foi imensa. A Segunda Carta de Direitos de Roosevelt foi integralmente contemplada pela Declaração Universal (artigos 22 a 26). Ao menos uma das muitas cadeias causais de eventos comunicativos por trás disso teve início no período inicial do New Deal, que culminou na primeira sentença da Declaraçâo Universal: "Todos os seres humanos nascem livres e iguais em dignidade e direitos" (artigo $1^{\circ}$ da Declaração Universal)..$^{53}$

Aquilo que o conceito de dignidade procurava expressar especificamente - e isso conduz a uma completa reinterpretação de nossos direitos - consistia no seguinte:

1. Unidade indissolúvel entre direitos políticos e sociais de liberdade.

2. Unidade indissolúvel entre direito nacional e internacional.

3. Validade universal do princípio constitucional internacional de cooperação e relações amistosas (que reforçavam os já vigentes princípios básicos da Carta da ONU). 
A influência da Declaração Universal foi enorme. Por insuficiente que tenha sido seu caráter vinculante, a maior parte de suas provisôes jurídicas estão atualmente contempladas num amplo espectro de documentos e instrumentos jurídicos vinculantes que instituíram mecanismos de aplicação e verificação, desde o Conselho da Europa, de 1949, até a Corte Interamericana de Direitos Humanos, de 1979, da Convenção Europeia de Direitos Humanos aos Acordos Internacionais de Direitos Humanos, de 1966, e do direito constitucional internacional ao imenso número de constituições nacionais, começando pelas constituições alemã e austríaca, após a Primeira Guerra Mundial, e chegando por fim a praticamente todas as novas constituiçōes que tenham sido estabelecidas após 1940 e, ainda mais importante, a reinterpretação radical de todas as antigas constituiçôes democráticas à luz da Carta da ONU e da Declaração Universal, algo a que sequer a Corte Suprema dos Estados Unidos consegue se eximir ao se ver sob pressão cada vez maior dos novos "padrōes das naçōes civilizadas" (Declaração de Independência) que foram estabelecidos após a Segunda Guerra Mundial. No início do século XXI, existe uma rede global de regimes de direitos humanos e civis que é tão densa que um efeito contra terceiros (Drittwirkung), um impacto horizontal dos direitos humanos sobre todas as esferas de açôes jurídicas, já começa a ser observado. ${ }^{54}$ Tomados em seu conjunto, esses indicadores mostram como existe atualmente um firme consenso constitucional global que consiste no reconhecimento da dignidade humana como a unidade inalienável dos direitos humanos politicos e sociais e dos direitos nacional e internacional (Sunstein, 2004, pp. 100ss). Sob o manto da dignidade, até mesmo os direitos não vinculantes (sociais, econômicos e culturais) do Segundo Acordo de 1966 adquirem um estatuto mais elevado do que o de meras declaraçōes.

A exclusão de desigualdades, que fora o princípio jurídico da integração normativa do moderno Estado nacional (Stichweh, 2000b, p. 52), tornou-se agora o princípio da integração normativa do direito mundial ou o princípio constitutivo do constitucionalismo global.

No limiar do século XXI, a ordem jurídica global consiste num número crescente de cortes internacionais (e de cortes nacionais com atuação internacional) no centro do sistema jurídico global (Bogdandy e Venzke, 2009); ${ }^{55}$ um sistema de politica global funcionalmente diferenciado, com cerca de 200 Estados nacionais e 250 organizaçōes internacionais, transnacionais e supranacionais de alcance global ou regional, com uma administração transnacional que tende a se mover de forma cada vez mais rápida rumo a seu centro (Kingsbury, Krisch e Steward, 2005; Möllers, 2005; Fischer-Lescano, 2008); um público mundial com sua própria agenda de prioridades; uma emergente cidadania global, que existe ao menos em seu estado negativo (Brunkhorst, 2005a, p. 338) ${ }^{56} \mathrm{e}$ uma sociedade civil de associações independentes, incluindo cerca de 27 mil organizações não governamentais (Held, 1995; Khan, 2001; Nickel, 2006)..$^{57}$

No entanto, até 1989, o processo de juridicização global e a constitucionalização tanto da política internacional como da economia global, assim como todos os outros sistemas funcionalmente diferenciados e as esferas especializadas de valor foram mantidos em estágios relativamente rudimentares. Somente após a queda do Muro de Berlim, a sociedade mundial normativamente integrada, que havia sido fundada imediatamente após 1945, foi finalizada e estabelecida em todo o mundo. Mas de agora em diante devemos ter em conta que a construção de uma sociedade mundial democrática ainda é (na melhor das hipóteses) um projeto inacabado. A promessa de 1945, renovada em 1989, foi de autodeterminação universal para indivíduos e povos e, em decorrência, democracia, mas, em seu lugar, o que alcançamos foi a universalização do capitalismo.

\section{Democracia perdida?}

O ano de 1989 foi importante, não como uma grande revolução, mas como a globalização da grande virada revolucionária do século $X X$, que se havia iniciado antes do fim da Primeira Guerra Mundial, com a Revolução Russa e a entrada dos Estados Unidos na guerra (Hobsbawm, 1995). Foi somente após 1989 que a rede de instituições internacionais 
construída durante e imediatamente após a Segunda Guerra Mundial passou a cobrir todo o planeta, não mais se detendo na Cortina de Ferro. Até mesmo a China agora segue não só as decisões vinculantes do regime de regras da Organização Mundial do Comércio, mas também o regime de soft law da Organização Mundial da Saúde (de modo mais ou menos relutante, mas a questão é que a cooperação se tornou, para bem ou para mal, incontornável). Mesmo a Rússia de Putin segue as decisões da Corte Europeia de Direitos Humanos. Sequer o Irã pode evitar a cooperação internacional a qual se vinculou por meio da Carta da ONU e do tratado de não proliferação nuclear.

Os eventos de 1989 viabilizaram a conclusão da construção de estruturas estatais pós-imperiais. Após a descolonização nas décadas de 1950 e 1960, a dessovietização do mundo na década de 1990 foi a segunda e última etapa no caminho do imperialismo rumo a um sistema global de Estados nacionais que fossem igualmente soberanos perante o direito internacional. $\mathrm{O}$ processo de descolonização universal foi resultado direto do novo direito internacional estabelecido com a Carta da ONU, sendo concluído somente após o fim do império da União Soviética. Somente a partir do momento em que o último metro quadrado de massa continental se tornou território estatal é que surgiu, como consequência imediata, a questão dos estados falidos, que se tornaram visíveis como um problema que afeta a comunidade internacional como um todo.

Após 1989, o novo sistema de direito internacional do pós-guerra foi finalmente globalizado. O caso Sakharov foi o ponto de virada, depois do qual Andrei Gromyko, o célebre "Mr. Nyet", passou a ser visto como alguém ainda mais obsoleto do que já era. Somente então deixou de ser viável a aplicação diferenciada de princípios: a coexistência pacífica e a absoluta não ingerência para além das fronteiras do Império (ou da esfera de influência) e a estreita cooperação e assistência fraterna reservada unicamente aos bons camaradas em Budapeste e Praga. A diferença entre moralidade imperial interna e externa ruiu e, quando os norte-americanos tentaram revivê-la, saindo à procura de um lugar específico de não ingerência assegurada, na Baía de Guantánamo, nem mesmo o juiz Antonin Scalia foi capaz de sustentar a defesa do isolacionismo que a Corte Suprema dos Estados Unidos havia procurado manter em relação ao direito internacional..$^{58}$ Independentemente disso, é importante ressaltar que mesmo o poderoso Império Soviético jamais abandonou o sistema de direito internacional estabelecido pela Carta da ONU. Ele apenas o interpretava de uma maneira muito unilateral, para então recorrer ao princípio das relações amistosas da Carta de 1945 (artigo I, 2) e da Declaração de 1970 (GA 2625, XXV) para justificar a assistência fraterna e ao princípio da "não ingerência" - ainda mencionado na Carta (artigo II, 7), mas severamente limitado não apenas pelo Capítulo VII, mas também pelos princípios universalmente aceitos dos direitos humanos (artigo I, 3) e da cooperação - para justificar as mesmas ações de assistência fraterna, assim como violações de direitos humanos em seu próprio território. ${ }^{59}$

Além disso, o acabamento do constitucionalismo democrático durante a década de 1990 inviabilizou qualquer alternativa séria à democracia, ao menos nos manuais jurídicos. China e Irã representam ainda exceções importantes. O Irã é uma teocracia constitucional (bastante comparável às monarquias constitucionais da Europa do século XIX, pelo menos até o verão de 2009) e a China, a despeito de possuir uma constituição democrática (baseada em grande medida no modelo da Constituição dos Estados Unidos), ainda reserva (de modo igualmente comparável às clássicas monarquias constitucionais) prerrogativas mais ou menos irrestritas ao Partido Comunista, apesar de ter havido mudanças consideráveis no sentido de assegurar direitos de propriedade e direitos humanos durante os últimos trinta anos, ao menos em termos simbólicos. ${ }^{60}$

Regimes antidemocráticos e opressivos em todo o mundo passaram a ser cada vez mais pressionados em razão de apelos pelo respeito aos direitos humanos, porque o (virtualmente já existente) público mundial e a sociedade civil se tornaram globais após 1989. O acesso aos meios globais de disseminação da informação não mais se detinha na fronteira oriental da Alemanha Ocidental, e a rede global de ONGs (associaçôes livres tocquevilianas no centro de qualquer sociedade civil) já não se detém nas fronteiras da China, do Irã ou da 
Rússia. Agora há um público mundial e uma sociedade civil global, apesar de serem muito mais vulneráveis ao poder social e político (desigualmente distribuído e não democrático), o que explica em parte a forte tendência que faz com que Estados recém-fundados se movam rumo à extrema direita no espectro político da arena internacional. ${ }^{61}$

Por fim, mas não menos importante, o capitalismo moderno (junto com todos os sistemas sociais funcionalmente diferenciados) tornou-se global e atualmente não enfrenta qualquer alternativa exterior, e esse é o problema.

A história mais uma vez se faz irônica. No momento de seu maior triunfo, a democracia é submetida à maior pressão. A nova ordem mundial pode ser - e de fato foi, e com razão - descrita como uma ordem constitucional. Mas o processo de constitucionalização não deve ser confundido com democratização. Esta é uma ilusão europeia, uma ilusão de juristas e teóricos políticos alemães, assim como a ideologia dos líderes da União Europeia e de seu maquinário de propaganda intelectual. A ilusão é que a juridicização e o estado de direito automaticamente conduzirão à democracia. São reveladores o nome e os desígnios da altamente influente Comissão de Veneza do Conselho da Europa, que desempenhou um papel importante nos processos de elaboração constitucional na Europa Oriental: "A Comissão Europeia para a Democracia através do Direito". Nesse caso, algo que normalmente se esquece mas que, não obstante, continua sendo constitutivo da crise de legitimação da União Europeia é que existe apenas um caminho que liga democracia ao direito; trata-se de um caminho que deve ser trilhado no sentido contrário: ao direito via democracia (Brunkhorst, 2006).

Juridicização e constitucionalização não são a solução para o problema da democracia europeia e cosmopolita, mas sim parte do problema. O dilema constitucional da sociedade mundial atual reside no fato de que a ilusão de complementaridade (paradigmaticamente expressa na sentença da Corte Constitucional Alemã sobre o Tratado de Lisboa) é ainda pior, e essa é a ilusão de que a democracia se encontra em segurança no interior das fronteiras do Estado nacional e pode ser salva se ali for mantida. A razão é simples. Tanto a juridicização como a constitucionalização da sociedade mundial são irreversíveis e permitem (desde a primeira grande onda de juridicização da política após a Revolução Papal do século XII) que algum progresso seja alcançado na estabilização das relações preexistentes e não democráticas de dominação e na emergência de novas configurações dessas mesmas relaçôes. Porém, como podemos ver claramente nos casos de todos os regimes neonacionalistas, toda regressão para estágios anteriores ao direito e à política pós-nacionais representa um passo a mais numa direção que normalmente conduz a algum tipo de regime fascista.

O novo e altamente fragmentado sistema constitucional da sociedade mundial inclui o poder administrativo do sistema de Estados, mas está muito longe de recuperar o controle sobre o sistema de capitalismo global que se converteu do confortável sistema de mercados apoiados no Estado do capitalismo tardio (quando Nixon dizia "Somos todos keynesianos") para o altamente desconfortável sistema de Estados apoiados no mercado do turbocapitalismo (Prien, 2010). Por ora parece que, desde 1989, quando o Estado nacional democrático se tornou global, o capitalismo triunfou sobre a democracia e, mesmo onde esta foi bem-sucedida, fez com que regressasse a uma "democracia de baixa intensidade" de mercados livres e eleições livres, não apenas no Leste, mas inclusive no Oeste (Marks, 2000).

O experimentalismo democrático de massas, a crescente inclusão social, política e cultural, o espírito de utopismo democrático igualitário e a autotranscendência, todos esses elementos, que impulsionaram o avanço democrático a partir $\mathrm{da}$ década de 1940 e da revolução global de direitos da década de 1960 e que ainda se encontram incorporadas em todos os nossos textos constitucionais, desapareceram rapidamente após 1989, em seguida à tecnocrática reunificação alemã (que tratou invençôes constitucionais, por exemplo as mesas-redondas, como eventos de política amadorística e considerou o poder constituinte digno apenas de manipulação inconstitucional). Esse foi somente o início de um processo de longo prazo que levou ao ressurgimento de um realismo político internacional tedioso (e profundamente irrealista); um renascimento de teorias schumpeterianas elitistas de de- 
mocracia (acompanhadas, na Alemanha, por uma teoria política afirmativa da nova burguesia) e da propaganda cultural nietzscheana de direita sobre a desigualdade estrutural dos homens (Sloterdijk); o triunfo da soberania estatal sobre a soberania popular e o elogio da governança sem governo democrático nos documentos da Comissão Europeia e na ciência política; ou a substituição da autolegislação igualitária pela pobre e velha ideia republicana de não dominação na filosofia política.

Por trás dessa "enorme superestrutura" (Marx) floresce uma nova infraestrutura, que se apoia especialmente na introdução de regimes regionais $e$ globais de soft law com força faticamente vinculante e passa ao largo do controle parlamentar e do escrutínio judicial. O resultado desses processos é a emergência e a estabilização de uma nova classe dominante econômico-politico-especialista, que, pela primeira vez na história, é realmente transnacional. O sonho do cosmopolitismo expresso pelo ícone do muro destruído foi realizado como o cosmopolitismo de poucos (Craig Calhoun). A imagem da atual sociedade mundial, como bem aponta Slavoj Žižek, "aproxima-se assustadoramente da mais exagerada imagem do capitalismo promovida pela tradição esquerdista: uma sociedade na qual a democracia formal meramente acoberta o domínio de uma minoria abastada" (New York Times, 9/11/2009).

No crepúsculo da socialdemocracia e do desaparecimento do movimento operário, não existem forças poderosas no horizonte capazes de organizar os interesses que poderiam mudar tanto o curso da história como da sociedade mundial, e o tão mal empregado conceito da "multidão" não pode, por definição, mudar o que quer que seja. Esse é o problema: o capitalismo é global, um sistema altamente produtivo, mas internamente catastrófico (Beckert, 2009), que de modo algum precisa da democracia e para o qual, infelizmente, não existe atualmente qualquer alternativa. Essa já é a catástrofe. Se a democracia algum dia terá a chance de domesticar aquilo que, por enquanto, ainda é o único sistema efetivamente global de capitalismo moderno e de lidar com suas crises e tendências catastróficas, é uma questão que permanece sem resposta.

\section{Notas}

1 A diferença entre Estado nacional e Estado-nação reside na "forte identidade linguística, religiosa e simbólica" deste último em detrimento daquele (Tilly, 1990, p. 3). Sobre as raízes que remontam aos séculos XII e XIII e que foram profundamente influenciadas pela ordenação legal da Igreja, ver Strayer (1970, 1956), Holister e Baldwin, 1978)

2 Constituição Alemã de 1871.

3 Karl Marx, Der 18. Brumaire, Mega, 112, citado a partir da versão eletrônica publicada em <http:// www.marxists.org/archive/marx/works/1852/18th-brumaire/ch02.htm>.

4 Utilizo o termo num sentido mais amplo que Luhmann, de modo a cobrir pontos de vista teóricos muito diversos, tais como Parsons (1961), Luhmann (1997a), Habermas (2005).

5 Basta ver a corrente infindável de eventos revolucionários que acompanha a formação do Estado nacional até hoje (Tilly, 1995).

6 Sobre esses elementos, ver Albert e Stichweh (2007); Shaw (2000); Chimni (2004).

7 Para uma crítica contundente do uso frívolo de governança, ver Offe (2009); para lançar luz sobre aqueles nas sombras, ver Dobner (2008); para uma discussão sobre o problema da responsabilidade, ver Kreide (2010).

8 Em termos luhmannianos, seria possível falar de um avanço evolucionário (Luhmann, 1997b, pp. 505ss).

9 Ver, entre outros, Seagle (1951); Hattenhauer (1992, pp. 66, 72); Höffe, 1999, p. 236).

10 Sou grato a Hubert Cancik pela discussão desse ponto.

11 Para uma crítica marcante e influente, ver os trabalhos de Hannah Arendt.

12 Essa tensão dialética no seio do mundo político é inteiramente negligenciada por Hannah Arendt.

13 Moore, DeBois, Berman, LeGoff.

14 Sobre a relação interna entre luta de classes e aprendizado normativo, ver Eder (1983)

15 Dictatus papae, c. 2, 8, 9.

16 "System der sich verwirklichenden Freiheit" (Hegel, 1983, p. 52, grifos meus). Ver também Kant (1977 e $1988, \$ 47,434)$.

17 A partir do século XVII, passou a ser chamado de Espelho dos Suábios, um compêndio normativo elaborado e publicado em 1275, em Augsburgo, por um monge franciscano, que, apoiando-se no Espe- 
lho dos Saxões e no Espelho dos Alemães, editados no início do século XII, coligia fontes normativas do Pentateuco, do direito romano e do direito canônico para descrever regimes normativos vigentes, sobretudo no âmbito do direito fundiário e feudatário (N. do T.).

18 Em razão de ambas as evoluções serem autônomas, minha tese da coevolução parece ser compatível com o pluralismo evolucionário e podemos deixar em aberto para investigação ulterior a questão sobre haver uma ou muitas evoluções da modernidade.

19 Cf. Berman (2004, 1983), Moore (2000), Brundage (1995, pp. 34, 39, 53, 55, 111, 154 164ss [positivação do direito]; 119 [modernidade]; 98ss [direito constitucional]; 62ss [profissionalização]; 80, 165ss [direitos subjetivos]; 152 [diferenciação funcional]); Landau (1996), Strayer (1970, 1956), Holister e Baldwin (1978), Tierney (1982, pp. 1, 16ss), Brundage (1994).

20 Cf. Brunkhorst (2005, cap. I. 3, p. 199); Möllers (2006b, pp. 202ss). Sobre o expansionismo democrático (federal), ver a já mencionada Arendt (1973).

21 "Povo" aqui é definido simplesmente como a população submetida ao governo não democrático, como os próprios americanos daquela época. Essa é uma das razôes pelas quais a Declaração trata do Bom Povo destas Colônias.

22 Para esta e as citaçôes seguintes, tradução livre de estrofes da canção Send the marines, de Tom Lehrer: "When someone makes a move/ Of which we don't approve/ Who is it that always intervenes?/ U.N. and O.A.S.,/ They have their place, I guess/ But first - send the Marines! [...] For might makes right,/ And till they've seen the light,/ They've got to be protected,/ All their rights respected,/ Till someone we like can be elected. [...] Stop calling it aggression,/ We hate that expression!/ We only want the world to know/ That we approve the status quo/ They love us everywhere we go,/ So when in doubt,/ Send the marines!"

23 Ver também a discussão entre os juízes Breyer e Scalia (2005) sobre a questão do direito internacional e transnacional e jurisdição.

24 Karl Marx, O 18 de Brumário de Luís Bonaparte. Texto integral disponível em <http://www.marxists.org/archive/marx/works/1852/18th-brumaire/ch02.htm>.

$25 \mathrm{Na}$ época, isso incluía a França e todos os outros países do mundo, com a única exceção dos Estados Unidos. O artigo 16 sintetiza toda a Revolução Francesa numa só sentença. Sobre a centralidade e o radicalis- mo teórico do artigo 16 da Declaração, ver Hofmann (1988).

26 Nesse sentido, a sentença da Corte Constitucional Alemã sobre os tratados de Lisboa é interessante, pois ignora inteiramente o potencial autotranscendente e as implicações cosmopolitas internas das constituições democráticas, tais como, na República Federal Alemã, a Grundgesetz (Lei Fundamental). O que escapa ao reconhecimento dos juízes é o próprio fulcro de todas as constituições democráticas, a saber: a autodeterminação democrática de um povo não se vincula à (e nem depende da) forma organizacional do altamente centralizado Estado moderno e nem tampouco à Santíssima Trindade de "território, povo e poder", que são constituídos por "Sua Majestade, o Estado". Cometer o erro de considerar que a nação como um sujeito autodeterminado seja meramente o outro lado de uma moeda cuja face é o Estado não faz mais do que repetir os velhos equívocos do positivismo estatutário da vontade de Estado, que caracterizaram a Alemanha pré-democrática do século XIX. A "redução estatista da tradição revolucionária", que vincula a autodeterminação democrática às fronteiras do Estado-nação, é um juízo equivocado e inconstitucional sobre o "conteúdo radical-democrático da doutrina do pouvoir constituant" (Möllers, 2006, p. 204, grifos do autor; em francês no original), justamente porque subsume a soberania popular à soberania do Estado. Em seu renitente estatismo hegeliano, os juízes esqueceram a simples evidência de que foi das Revoluçôes Americana e Francesa que o cosmopolitanismo "recebeu seus impulsos mais fortes" (Kleingeld e Brown, s/d). A autotranscendência cosmopolita é - a contrapelo da influente, mas simplesmente errônea (porque substantivista e irracional) interpretação de Carl Schmitt sobre Sieyès em sua Doutrina Constitucional (Verfassungslehre) - uma implicação interna da constituição revolucionária do poder constituinte.

27 Ver Parsons (1961), Mosler (1980), Verdross e Simma (1984). Sobre a discussão recente, ver Tomuschat (1993, 1995), Fassbender (1998, recentemente expandido e desenvolvido num livro de mesmo título, 2009), Paulus (2001), Frowein (2001), Fischer-Lescano (2005), Emmerich-Fritsche (2007), Bogdandy (2006), Berman (1995), Brunkhorst (2002a, 2005b), Teubner (2003), Luhmann (1993, p. 582), Habermas (2004, 2005), Möllers (2006c), Müller (2003); Bogdandy et al. (2009).

28 Sobre a tese da revolução jurídica do século $\mathrm{XX}$, ver Brunkhorst (2008a e b). 
29 Guerras, ganhas ou perdidas, usualmente geram processos revolucionários, e todas as grandes revoluções ocorrem não apenas em meio a lutas internas por poder ou guerras civis, mas também em meio a guerras, como evidenciam os casos da Revolução Papal, da Reforma Protestante, da Revolução Inglesa e das Revoluçōes Americana e Francesa. Essa é uma das razões pelas quais, na França, mas especialmente nos Estados Unidos, as guerras geralmente são interpretadas, ou ao menos justificadas ideologicamente, como guerras "revolucionárias" (o caso mais recente foi a guerra ilegal de agressão lançada por Bush contra o Iraque em 2003). Entretanto, em alguns casos, essas justificaçôes não são meras formas de mascarar um imperialismo sangrento, como no caso mencionado.

30 A introdução de um "tribunal especial" contra um individuo (Guilherme II), acusado "por uma suma ofensa contra a moralidade internacional e a santidade dos tratados" (artigo 227), a introdução de "tribunais militares" para "pessoas acusadas de cometer atos de violência que violam as leis e costumes da guerra" (artigo 228) e para "pessoas culpadas de atos criminosos praticados contra os cidadãos de uma das Potências Aliadas ou Associadas" (artigo 229), além da obrigação do Estado (alemão) de apresentar aos tribunais todas as informações relevantes. Por mais unilateral que tenha sido, foi o primeiro passo no sentido da criação de uma subjetividade jurídica que contemplasse os seres humanos individuais no direito internacional.

31 Cf. Fassbender (2009, p. 103); ver também Lauterpacht (1936, p. 54); sobre o caráter revolucionário do Tratado de Versalhes, ver Kelsen (1920, pp. 3-4; 1932, pp. 151 e 155; Hoss (2008, pp. 157ss); Bernstorff (2001, pp. 128ss). Toda a construção (wilsoniana) do Acordo seguiu estritamente o esboço de 1795 de Kant para uma Liga das Nações: ver Beestermöller (1995); Eberl (2007, p. 75).

32 O artigo 20 estipula: "Os Membros da Liga solidariamente pactuam que este Acordo é aceito como uma ab-rogação de todas as obrigações ou entendimentos entre eles que porventura sejam inconsistentes com seus termos e solenemente se obrigam a doravante não assumir quaisquer compromissos inconsistentes com seus termos. No caso de algum Membro da Liga ter, antes de se tornar Membro da Liga, assumido quaisquer obrigaçôes inconsistentes com os termos do Acordo, será dever desse Membro tomar providências imediatas para se desonerar de tais obrigações".

33 Os casos estão relacionados com a legalidade da aplicação de sanções econômicas contra indivíduos, tendo a Corte Europeia de Justiça (CEJ) rejeitado as sentenças da Corte de Primeira Instância em ambos os casos e anulado a Regulação 881/2002 do Conselho Europeu, que havia imposto medidas restritivas contra pessoas e entidades associadas a Ossama bin Laden, à rede al-Qaida ou aos Talibã, porque entendeu que era incompatível com os direitos fundamentais reconhecidos pela União Europeia.

34 A primeira monografia a ostentar em seu título uma variante de constituição de direito internacional já havia aparecido após a Primeira Guerra Mundial, remetendo a uma ampla discussão travada durante a guerra (ver Verdross, 1926). Sobre a discussão alemã, ver Eberl (2007); sobre a discussão francesa da época, ver Wüst (2007); sobre os casos Kadi e Yusuf, ver Ley (2007), Möllers (2006a) e Halberstam (2010, p.18).

35 Qualquer distinção útil entre constitucionalismo evolucionário e revolucionário deve ter em conta que essas duas fórmulas não pertencem a mundos distintos, sendo historicamente interconexas de formas que serão descritas adiante.

36 A respeito da conexão causal entre o constitucionalismo revolucionário da Revolução Francesa e a emergência das monarquias constitucionais no século XIX, ver Sellin (2001); sobre o processo de juridicização, ver Grimm (1987); sobre a ocidentalização e o reformismo legal na Rússia após a Revolução Francesa, ver Berman (1963, p. 13).

37 A respeito desse papel dos interesses no desenvolvimento evolucionário, ver Luhmann (1997b).

38 Uma análise brilhante desse aspecto pode ser encontrada em Moore (2000).

39 A tradução oficial alemã revela-se, portanto, profundamente equivocada, pois substitui "Membros" no art. 2 I por "Estados", num exemplo linguístico de positivismo da vontade de Estado.

40 Sobre crescimento, ver Thomas Franck (Book Review, vol. 77, Harvard law Review 1565, 1964) apud Fassbender (1998, p. 5); sobre a fragmentação (e desconstitucionalização), ver Koskenniemi (2004), Koskenniemi e Leino (2002), Bast (2009); sobre o processo simultâneo de constitucionalização por coordenação e acomodação, ver Halberstam (2010).

41 Criando um estágio pós-convencional de argumentação e solução de conflitos para disputas morais e legais de acordo com Piaget e Kohlberg. Ver Habermas (1976b), com um paradigma procedimental de teoria jurídica que representa o desenvolvimento ulterior dos discursos pós-convencionais. 
42 Versōes finais do refrão do hino socialista $A$ Internacional, em sua versão alemã, Auf zum letzten Gefecht/ Die Internationale erkämpft das Menschenrecht" (N. do T.).

43 A Constituição declara, em seu artigo 2 V 13, o "direito à propaganda religiosa e antirreligiosa, que os artigos 14 ("liberdade de expressão") e 15 ("liberdade de reunião") têm de se concretizar materialmente, em especial para "a classe trabalhadora e o campesinato mais pobre", que o artigo 16 ("assistência, material e de outra natureza"), deve ser assegurada aos trabalhadores e aos camponeses mais pobres "em seu esforço por unirem-se e organizarem-se", que o artigo 17 ("educação gratuita, plena e geral, para a classe trabalhadora e o campesinato mais pobre") deve ser garantido, e estatui ainda os artigos 21 (oferta de "asilo a todos os estrangeiros que busquem refúgio de perseguição política e religiosa”) e 22 (“direitos iguais a todos os cidadãos, independente de conexões raciais ou nacionais" e que todos os "privilégios assentados sobre essas bases, assim como a opressão de minorias nacionais" são "proclamados" "contrários à lei fundamental da República", além do artigo 4 XIII 64, que estipula o "direito ao voto" para "ambos os sexos, independente de religião, nacionalidade, domicílio etc.".

44 Disponível em <http://www.ilo.org/ilolex/english/ iloconst.htm>.

45 Ver a brilhante análise de Parsons (1961).

46 Para a demanda por emenda, ver Cong. Rec. 79, 1935, pp. 14 e 212 (Statement by Rep. Hildebrandt).

47 Atlantic Charter. Disponível em <http://www.internet-esq.com/ussaugusta/atlantic1.htm>. A Carta era expressamente universal e explicitamente dirigida a "todos os Estados, grandes ou pequenos, vitoriosos ou vencidos".

48 UN General Assembly, Declaration of Principles of International Law Concerning Friendly Relations and Co-operation Among States in Accordance with the Charter of the United Nations, 24 October 1970. Disponível em <http://www.unhcr.org/refworld/ docid/3dda1f104.html $>$, acessado em 4 de março de 2010.

49 "Adequado", nesse caso, significa, antes de tudo, normativamente adequado, pois a nova interpretação de nossos direitos pretende ser "universal" (Merriam, 1946, pp. 11 e 15).

50 No original: "Die Würde der Menschheit besteht (in der) Fähigkeit, allgemein gesetzgebend [...] zu sein".

51 Em consonância com Maus, ver Habermas (1976b); Möllers (1999); Brunkhorst (2002b).
52 Sobre as outras fontes, ver McCrudden (2008); Müller (2008).

53 O Preâmbulo da Declaração Universal já sustenta que "a dignidade e o valor da pessoa humana", juntamente com "os direitos iguais de homens e mulheres", "determinam" que "os povos das Nações Unidas" "promovam o progresso social e melhores padrões de vida em condições de maior liberdade". Para que ao homem lhe sejam reconhecidos "a dignidade e o livre desenvolvimento de sua personalidade", alguns direitos são, como prescreve o artigo 22, "indispensáveis" e seu fulcro consiste no "direito à seguridade social" e na garantia da "realização, através do esforço nacional e da cooperação internacional [...], dos direitos econômicos, sociais e culturais" (artigo 22; ver ainda o artigo $23 \mathrm{II})$.

54 Ver "Transcript of Discussion Between Breyer and Scalia"; também Supreme Court 08-7412 (nov. 9, 2009), disponível em <http://www.supremecourt. gov/opinions/09pdf/08-7412.pdf>. Ver ainda (e especialmente sobre Drittwirkung [efeitos contra terceiros]): Bogdandy e Venzke (2009), Teubner (2003) e Nickel (2009).

55 Nas duas últimas décadas, foram registradas mais de 75\% de todas as decisões (cerca de 25 mil) já tomadas historicamente por tribunais supranacionais (ver Alter, 2008, pp. 28ss); sobre a centralidade do sistema de tribunais no sistema jurídico mundial, ver Fischer-Lescano (2005).

56 Sobre o impacto empírico do público mundial, ver Risse, Ropp e Sikkink (1999). Sobre a cidadania mundial e o desenvolvimento desse conceito desde o século XVIII, ver Stichweh (2000a pp. 2, 8ss). Em 0,36 segundo, Google encontra 91.900.000 itens relacionados com a opinião pública mundial (em sua formulação em inglês [world public opinion]) e, em 0,34 segundo, 1.010.000.000 ocorrências para público mundial (também em inglês [world public]; em maio de 2007, eram apenas $672 \mathrm{mil}$.

5757 . Sobre o problema jurídico da participação de ONGs em organizaçōes internacionais, ver Bernstorf (2008). Para mais trabalhos de pesquisa a respeito e fontes eletrônicas, ver NGO Research Guide, disponível em <http://library.duke.edu/research/subject/ guides/ngo_guide/ngo_links/a-e.html>.

58 A esse respeito, ver Nickel (2009).

59 Isso reflete claramente a debilidade do texto da Carta da ONU, que permite que tanto os críticos do princípio da não ingerência como seus defensores possam sustentar suas respectivas posições com ar- 
gumentos jurídicos bem fundados. Algo que ocorre ao longo de toda a Carta e que definitivamente foi demonstrado por Kelsen em seu comentário de mais de mil páginas sobre o documento (e que ainda é o comentário mais usado quando se trata do processo decisório das Nações Unidas). Ver Kelsen (1950). É a debilidade da Carta, porém, que possibilita sua alta flexibilidade, sendo uma das razões pelas quais opera comparativamente bem e tenha sobrevivido a inúmeras crises.

$60 \mathrm{O}$ desenvolvimento do socialismo soviético é muito diferente do da China, o que pode ser explicado por duas causas. Primeiro, após a era totalitária do stalinismo, grandes esforços foram feitos para reformar o socialismo, durante o governo de Khrushchev e posteriormente sob Brezhnev. Contudo, nem em termos jurídicos e nem em termos econômicos, foram capazes de estabelecer o estado de direito ou uma verdadeira sociedade socialista de consumo. Além disso, depois que os tanques entraram em Praga para manter sob controle o socialismo com face humana, os últimos vestígios de uma fachada de legitimidade já arranhada foram removidos. Isso tornou o regime completamente incapaz de se reformar e, por isso, a primeira tentativa de reforma sob Gorbachev foi também o primeiro passo na direção do abismo. Pois nem a nomenklatura comunista acreditava mais no socialismo soviético, todas as alternativas já haviam sido reduzidas a tanques ou mudança de regime e de sistema. Com a China foi muito diferente. Ali, a transformação do comunismo autoritário de partido único, que havia começado imediatamente após sua era totalitária, ainda tinha uma camada muito mais espessa de crença em sua legitimidade e poderia ser imposta como um movimento no sentido do estabelecimento de um capitalismo autoritário, que já possuía uma longa e, ao menos parcialmente, muito bem sucedida tradição no Ocidente (de Luís Bonaparte, passando por Mussolini e Hitler, até chegar a Pinochet) e, em especial, no Extremo Oriente (vide o caso do Japão).

61 Um dos efeitos mais marcantes da rápida emergência de um público global como decorrência dos eventos de 1989 foi psicológico e consistiu na ampla universalização e completa descentralização do racionalismo ocidental, fazendo com que o racionalismo não mais estivesse associado ao Ocidente e, portanto, pudesse ser (e, de fato, imediatamente fosse) interpretado a partir de perspectivas sociais, regionais e culturais muito diversas. Assim, a modernidade, que, por muito tempo, parecia haver sido a exceção europeia (e americana), pluralizou-se em múltiplas (embora emaranhadas) mo- dernidades. Apesar disso, é preciso não perder de vista que existe apenas uma única cultura racional mundial e uma única sociedade mundial, visto que a extremamente artificial autoexclusão do socialismo autoritário e imperial havia cessado em 1989. Isso não minimiza, porém, as diferenças, as tensões e as contradiçōes sociais e culturais internas e até mesmo estruturais da sociedade mundial; pelo contrário, maximiza-as, criando constantemente novas oposições e fazendo com que explodam suas tensôes.

\section{BIBLIOGRAFIA}

ACKERMAN, Bruce. (1998), We the people. Vol 2: Transformations. Cambridge MA, Harvard University Press.

ALBERT. (2005), "Politik der Weltgesellschaft und Politik der Globalisierung: Überlegungen zur Emergenz von Weltstaatlichkeit”. Zeitschrift für Soziologie, 223-239.

ALBERT, Mathias \& STICHWEH, Rudolf (eds.). (2007), Weltstaat und Weltstaatlichkeit. Wiesbaden: Verlag für Sozialwissenschaften.

ALLOT, Philip. (1990), Eunomia: new order for a new world. Oxford, Oxford of University Press.

ALTER, Karen. (2008), "Delegating to international courts: self-binding vs. other-binding delegation". Law and Contemporary Problems, 67.

ANGHIE, Antony. (2004), Imperialism, sovereignty and the making of international law. Cambridge MA, Cambridge University Press.

ARENDT, Hannah. (1973), On Revolution. Harmondsworth, Penguin.

BAST, Jürgen. (2009), "Das Demokratiedefizit fragmentierter Internationalisierung”, in $\mathrm{H}$. Brunkhorst, Demokratie in der Weltgesellschaft, Baden-Baden, Nomos.

BECKERT, Jens. (2009), "Die Anspruchsinflation des Wirtschaftssystems“. Manuscrito eletrônico inédito de uma palestra proferida na Universidade Técnica de Zurique, em 28 maio.

BEESTERMÖLLER, Gerhard. (1995), Die Völkerbundidee. Stuttgart, Kohlhammer.

BERMAN. (1963), Justice in the USSR. Cambridge MA, Harvard University Press. 
BERMAN, Harold J. (1983a), Law and revolution: the formation of the Western legal tradition. Cambridge MA, Harvard University Press. . (1983b), The Formation of the Western Legal Tradition, Cambridge MA: Harvard University Press.

. (1995), "World law". Fordham International Law Journal, 18: 1617-1622.

(2004), Law and Revolution II: the impact of the protestant reformation on the Western legal tradition. Cambridge, MA, Harvard University Press.

BERMAN. (2005), "Faith and Law in a Multicultural World”, in Mark Juergensmeyer (ed.), Religion in global civil society, Oxford, Oxford of University Press, pp. 69-89.

BERNSTORF, Jochen Von. (2001), Der Glaube an das universale Recht: zur Völkerrechtstheorie Hans Kelsens und seiner Schüler. Baden-Baden, Nomos. (2008), "Procedures of decision-making and the role of law in international organizations". Versão preliminar apresentada no Instituto Max Planck de Direito Público, em Heidelberg.

BHUTA, Nehal. (2010), "New Modes and orders: the difficulties of a jus post bellum of constitutional transformation". Institute for International Law and Justice New York University School of Law, Working Paper 1.

BOGDANDY, Armin von. (2006), "Constitutionalism in international law". Harvard International Law Journal, 47: 223-242.

BLICKLE, Peter (2003). Von der Leibeigenschaft $z u$ den Menschenrechten. Eine Geschichte der Freiheit in Deutschland. Munique, C. H. Beck.

BOGDANDY, A. von \& VENZKE, Ingo. (2009), "In wessen Namen? Die internationale Gerichtsbarkeit diskurstheoretisch betrachtet". Palestra proferida em Zurique em 28 maio.

BOGDANDY, A. von; WOLFRUM, Rüdiger; BERNSTORFF, Jochen von; DANN, Philipp \& GOLDMANN, Matthias (eds.). (2009), The exercise of public authority by international institutions: advancing international institutional law. Heidelberg, Springer.

BREYER, S \& SCALIA, A. (2005), "Transcript of discussion between U.S. Supreme Court Justi- ces .Washington College of Law, Jan. 13. Disponível em <http://domino.american.edu/AU/ media/mediarel.nsf/1D265343BDC2189785 256B810071F238/1F2F7DC4757FD01E85 256F890068E6E0?OpenDocument $>$.

BRUNDAGE, J. A. (1994), "The rise of the professional jurist in the Thirteenth Century". Syracuse Journal of International Law and Commerce, 20: 185-190.

(1995), Medieval canon law. London/ Nova York, Longman.

BRUNKHORST, Hauke. (1990), Theodor W. Adorno: Dialektik der Moderne. Munique, Piper.

(ed). (1998), Demokratischer Experimentalismus. Politik in der komplexen Gesellschaft. Frankfurt am Main, Suhrkamp Verlag. . (2000), Einführung in die Geschichte politischer Ideen. Munique, Fink-UTB.

(2002a), "Globalising democracy without a State: weak public, strong public, global constitutionalism". Millenium: Journal of International Studies, 31: 675-690.

(2002b), Solidarität. Von der Bürgerfreundschaft zur globalen Rechtsgenossenschaft. Frankfurt am Main, Suhrkamp Taschenbuch Wissenschaft.

(2005a), Solidarity: from civic friendship to a global legal community. Cambridge MA/Londres, The MIT Press.

. (2005b), "Demokratie in der globalen Rechtsgenossenschaft. Einige Überlegungen zur poststaatlichen Verfassung der Weltgesellschaft". Zeitschrift für Soziologie (ZfS): Sonderheft Weltgesellschaft, 34: 330-347.

. (2006), "The legitimation crisis of the European Union”. Constellations, 13: 165-180. . (2007), "Unbezähmbare Öffentlichkeit. Europa zwischen transnationaler Klassenherrschaft und egalitärer Konstitutionalisierung". Leviathan, 1/7: 12-29.

. (2008a), "Die Globale Rechtsrevolution. Von der Evolution der Verfassungsrevolution zur Revolution der Verfassungsevolution?", in Ralph Christensen e Bodo Pieroth (eds.), Rechtstheorie in rechtspraktischer Absicht, Berlin, Dunker \& Humblot, pp. 9-34. 
. (2008b), "Kritik am Dualismus des internationalen Recht - Hans Kelsen und die Völkerrechtsrevolution des 20. Jahrhunderts”, in Regina Kreide e Andreas Niederberger (eds.), Internationale Verrechtlichung. Nationale Demokratien im Zeitalter globaler Politik, Frankfurt am Main-New York, Campus, pp. 30-63.

BRUNKHORST, Hauke \& KOCH, Gertrud. (2005), "The Man who shot Liberty Valance: un conte juridique". Trafic. Revue de Cinéma, 56, pp. 134-58.

BRUNKHORST, Recht. (2009), "Revolution und Evolution”. Manuscrito inédito.

BRUNS-SCHMALZ, R. (2010) "Democratic legitimacy, political normativity and statehood", in Erik Oddvar Eriksen e John Erik Fossum (eds.), What democracy for Europe? Oslo, Arena.

BYERS, Michael. (2003), "Pre-emptive self-defense: hegemony, equality and strategies of legal change". The Journal of Political Philosophy, 11: 171-190.

CANTOR, N. (1969), Medieval history: the life and death of a civilization. Nova York, Macmillan, 1969.

CHIMNI, B. S. (2004), "International institutions today: an imperial global state in the making". European Journal of International Law, 15 (1): 1-37.

DEWEY, John. (1984), The public and its problems: the later works 1925-1953. Carbondale IL, Southern Illinois University Press.

DI FABIO, Udo. (1998), Das Recht offener Staaten. Grundlinien einer Staats- und Rechtstheorie. Tübingen, Mohr.

DOBNER, Petra. (2008), "Did the state fail? Zur Transnationalisierung und Privatisierung der öffentlichen Daseinsfürsorge: Die Reform der globalen Trinkwasserpolitik". Manuscrito inédito.

EBERL, Oliver. (2007), Demokratie und Frieden. Kants Friedensschrift in den Kontroversen über die Gestaltung globaler Ordnung. Diss. Univ. Bremen.

EDER, Klaus. (1983), "Collective learning processes and social evolution: towards a theory of class conflict in modern society". Tidskrift for Rätssociologi, 1: 23-36.
EMMERICH-FRITSCHE, Angelika. (2007), Vom Völkerrecht zum Weltrecht. Berlim, Duncker \& Humblot.

FASSBENDER, Bardo. (1998), “The United Nations Charter as Constitution of the international community". Columbia Journal of Transnational Law, 36: 529-619. (2009), The United Nations Charter as the Constitution of the International Community. Leiden-Boston MA, Nijhoff.

FISCHER-LESCANO, Andreas. (2005), Globalverfassung: Die Geltungsbegründung der Menschenrechte. Weilerwist, Vellbrück.

. (2008), "Transnationales Verwaltungsecht". Juristen-Zeitung, 63: 373-383.

FRIED, J. (1974), Die Entstehung des Juristenstandes im 12. Jahrhundert. Zur sozialen und politischen Bedeutung gelehrter Juristen in Bologna und ModenaColônia/Viena, Böhlau..

FROWEIN, Jochen A. (2001), "Konstitutionalisierung des Völkerrechts", in BDGVR, Völkerrecht und Internationales Recht in einem sich globalisierenden internationalen System, Heidelberg, C. F. Müller.

GOODWIN, Doris Kearns. (1994), No ordinary time: Franklin and Eleanor Roosevelt. Nova York, Simon \& Schuster.

GRIMM, Dieter. (1973), Solidarität als Rechtsprinzip. Die Rechts- und Staatslehre Léon Duguits in ihrer Zeit. Frankfurt am Main, Athenäum. (1987), Recht und Staat in der bürgerlichen Gesellschaft. Frankfurt, Suhrkamp.

HABERMAS, Jürgen. (1976a), Zur Rekonstruktion des Historischen Materialismus. Frankfurt, AM, Suhrkamp. (1976b), "Faktizität und Geltung", in Zur Rekonstruktion des Historischen Materialismus, Frankfurt, AM, Suhrkamp. (2004), "Hat die Konstitutionalisierung des Völkerrechts noch eine Chance?”, in , Der gespaltene Westen, Frankfurt am Main, Suhrkamp, pp. 113-193.

(2005), "Eine politische Verfassung für die pluralistische Weltgesellschaft?", in , Zwischen Naturalismus und Religion, Frankfurt am Main, Suhrkamp, pp. 324-365. 
. (2009), "Das Konzept der Menschenwuerde und die realistische Utopie der Menschenrechte”. Manuscrito inédito.

HALBERSTAM, Daniel. (2008), "Constitutional heterarchy: the centrality of conflict in the European Union and the United States". Michigan Law Working Papers, 111.

. (2010), "Local, global, and plural constitutionalism, in G. de Búrca e J. H. H. Weiler (eds.), The worlds of European constitutionalism, Cambridge, Cambridge University Press, pp. 1-38.

HATTENHAUER, Hans. (1992), Europäische Rechtsgeschichte. Heidelberg, C. F. Müller

HEGEL, G. W. F. (1970), Grundlinien der Philosophie des Rechts [Werke, vol. 7]. Frankfurt, Suhrkamp. . (1983), Philosophie des Rechts. Frankfurt: Suhrkamp.

HELD, David. (1995), Democracy and the global order: from the modern State to cosmopolitan governance. Oxford, Polity Press.

HOBBES, Thomas. (1971), A dialogue between a philosopher and a student of the Common Laws of England. Chicago, University of Chicago Press.

HOBSBAWM, Eric J. (1987), The age of Empire 1875-1914. Londres, Weidenfeld. . (1995), The age of extremes: the short Twentieth Century 1914-1991. Londres, Abacus.

HÖFFE, O. (1999), Demokratie im Zeitalter der Globalisierung. München, Beck.

HOFMANN, Hasso. (1988), "Zur Herkunft der Menschenrechtserklärungen”. Juristisches Studium, 11: 840-848.

HOLISTER, C. Warren \& BALDWIN, John W. (1978), "The rise of administrative kingship: Henry I and Phillip Augustus". AHR, 83: 867-905.

HOSS, Cristina. (2008), "Kelsen in Den Haag. Die Haager Vorlesungen von Hans Kelsen”, in H. Brunkhorst e Rüdiger Voigt (eds.), Rechts-Staat, Baden-Baden: Nomos, pp. 149-168.

JOERGES, Christan; TEUBNER, Gunther \& SAND, Inger-Johanne. (2004), Transnational governance and constitutionalism. Oxford, Hart. KANT, Immanuel. (1977), Grundlegung Metaphy- sik der Sitten. [Werke, vol. VIII]. Frankfurt, Suhrkamp,

KANT, Immanuel. (1988), Rechtslehre. Schriften zur Rechtsphilosophie (ed. Hermann Klenner). Berlim, Akademie.

KATZNELSON, Ira. (2005), When affirmative action was white: an untold history of racial inequality in Twentieth-Century America. Nova York/Londres, W.W. Norton.

KELSEN, Hans. (1920), "Der völkerrechtliche Strafanspruch wegen völkerrechtswidriger Kriegshandlungen”. Neue Freie Presse, 8, set. . (1932), "La théorie générale du Droit International Public". Recueil des Cours de l'Académie de Droit International, 42: 117-351. . (1950), The law of the United Nations: a critical analysis and its fundamental problems. Nova York, Praeger. . ([1920] 1981), Das Problem der Souveränität und die Theorie des Völkerrechts. Aalen, Scientia Verlag.

KHAN, Rhamatulla. (2001), "The anti-globalization protests: side-show of global governance, or law-making on the streets?”. Zeitschrift für ausländisches öffentliches Recht und Völkerrecht, pp. 323-355.

KINGSBURY, Benedict; KRISCH, Nico \& STEWARD, Richard B. (2005), "The emergence of global administrative law”. Disponível em <http://law.duke.edu/journals/lcp>.

KLEINGELD, Pauline. (2006), "Cosmopolitanism”. Stanford Encyclopaedia of Philosophy. Disponível em <http://plato.stanford.edu/entries/cosmopolitanism/>.

KLEINGELD, Pauline \& BROWN, Eric. (s/d), "Cosmopolitanism". Stanford Encyclopaedia of Philosophy. Disponível em <http://plato.stanford.edu/entries/cosmopolitanism $>$.

KOSKENNIEMI, Martti. (2001), The gentle civilizer of nations: the rise and fall of international law 1870-1960. Cambridge, Cambridge University Press.

. (2004), "Global governance and public international law". Kritische Justiz, 37: 241-254.

KOSKENNIEMI, Martti \& LEINO, Päivi. (2002), "Fragmentation of international law. 
Postmodern anxieties?". Leiden Journal of International Law, 15: 553-579.

KREIDE, Regina. (2010), "The responsibility of Non-State Actors: transnational corporations and human rights obligations". Manuscrito inédito.

LANDAU, P. (1996), "Die Bedeutung des kanonischen Rechts für die Entwicklung einheitlicher Rechtsprinzipien", in Heinrich Scholler (ed.), Die Bedeutung des kanonischen Rechts für die Entwicklung einheitlicher Rechtsprinzipien, Baden-Baden, Nomos, pp. 23-47.

LAUTERPACHT, Hersch. (1936), "The covenant as the "Higher Law'. British Year Book of International Law, 17, Nova York/Londres, Oxford University Press.

LEISERING, Lutz. (2007), "Gibt es einen Weltwohlfahrtsstaat?", in Mathias Albert e R. Stichweh (eds.), Weltstaat und Weltstaatlichkeit, Wiesbaden, Verlag für Sozialwissenschaften, , pp. 185-205.

LEY, Isabelle. (2007), "Legal protection against the UN-Security Council. Between European and International Law: A Kafkaesque Situation?”. German Law Journal, 8: 279-293.

. (2010), "Brünn betreibt die Parlamentarisierung des Primärrechts. Anmerkungen zum zweiten Urteil des tschechischen Verfassungsgerichtshofs zum Vertrag von Lissabon vom 3.11.2009”. Juristen Zeitung, pp. 165174.

LUHMANN, Niklas. (1993), Das Recht der Gesellschaft. Frankfurt am Main, Suhrkamp. . (1997a), "Globalization or world society: how to conceive of modern society?". International Review of Sociology, 7: 67-80. (1997b), Die Gesellschaft der Gesellschaft. Frankfurt am Main, Suhrkamp.

MADDOX, G. (1996), Religion and the rise of democracy. Nova York/Londres, Routledge.

MARKS, Susan. (2000), The Riddle of all Constitutions, (Oxford: Oxford University Press, 2000

MARX, Karl. (1851), "The Constitution of the French Republic", in Notes to the People, 7 [edição londrina], 14 de junho de 1851. Disponível em <http://www.marxists.org/archive/ marx/works/1851/06/14.htm>.
MARX, Karl. (1966), “Zur Judenfrage”, in: Marx e Engels, I Studienausgabe: Philosophie [ed. Fetscher], Frankfurt am Main, Fischer.

MAUL, Daniel. (2010), "The ILO involvement in decolonisation and development, ILO Century Project 2010. Disponível em <http:// www.ilo.org/public/english/century/information_resources/download/maul.pdf s.

MAUS, Ingeborg. (1990), „Zur Theorie der Institutionalisierung bei Kant", in G. Göhler et al. (eds.), Politische Institutionen im gesellschaftlichen Umbruch, Opladen, Westdeutscher Verlag, pp. 358-385.

. (1992), Zur Aufklärung der Demokratietheorie. Frankfurt am Main, Suhrkamp.

McCARTHY, Tom. (2009), Race, empire, and the idea of human development. Cambridge MA, Cambridge University Press.

McCRUDDEN, Christopher. (2008), "Human dignity and judicial interpretation of human rights". The European Journal of International Law, 19: 655-724.

MERRIAM, Charles E. (1946), "The content of an international bill of rights", in W. D Lewis e J. R. Ellinston (eds.), Annals of the American Academy. Vol. 243: Essential Human Rights (republicado em Sage Publications/JSTOR, disponível em <http://www.jstor.org/pss/1025049>.

MÖLLERS, Christoph. (1999), Staat als Argument. München, C. H. Beck Verlag. (2005), "Transnationale Behördenkooperation". Zeitschrift für ausländisches öffentliches Recht und Völkerrecht, 17: 351-389.

. (2006a), "Das EUG konstitutionalisiert die Vereinten Nationen", in J. P. Terhechte (ed.), Europarecht 3. Baden-Baden: Nomos, pp. 426-431.

. (2006b), "Pouvoir Constituant", in

A. von Bogdandy e J. Bast (eds.), Principles of European constitutional law. Oxford/Portland, Hart Publisher/Oregon. (2006c), Gewaltengliederung. Tübingen, Mohr.

MOORE, Barrington. (1978), Injustice: the social bases of obedience and revolt. Nova York, Sharpe. MOORE, R. I. (2000), First European revolution. Oxford/Malden, Mass., Blackwell. 
. (2001), Die Erste Europäische Revolution. Gesellschaft und Kultur im Hochmittelalter. München, Beck.

MOSLER, Hermann. (1980), The international society as a legal community. Alphen, Sijthoff $\&$ Noordhoff.

MÜLLER, Friedrich. (2003), Demokratie zwischen Staatsrecht und Weltrecht. Nationale, staatlose und globale Formen menschenrechtsgestützter Globalisierung. Elemente einer Verfassungstheorie VIII. Berlim, Duncker \& Humblot.

MÜLLER, Jan Werner. (2008), "Die eigentlich katholische Verschärfung. Jacques Maritain und die christdemokratischen Fluchtwege aus dem Zeitalter der Extreme". Zeitschrift für Ideengeschichte, II (3): 40-54.

NICKEL, Rainer. (2006), "Participatory transnational governance", in Christian Joerges e Ernst-Ulrich Petersmann (eds.), Constitutionalism, multilevel trade governance and social regulation. Oxford, Hart Publishing. Disponível em <http://ssrn.com/abstractid=885380 $>$. . (2007), "The missing link in global law: regime collisions, societal constitutionalism, and participation in global governance", in Nicolás López Calera (ed.), Globalisation, law and economy, Stuttgart, Franz Steiner Verlag, 2007, vol. VI, pp. 237-250.

(2009), "Transnational borrowing among judges: towards a Common Core of European and global constitutional law?", in (ed.), Conflicts of law and laws of conflict in Europe and beyond, Oslo, Arena, pp. 281-306.

OFFE, Claus. (2009), "Governance: An Empty Signifier?”. Constellations, 16 (4): 550-562.

PARSONS, Talcott. (1961), "Order and community in the international social system", in James N. Rosenau (ed.), International politics and foreign policy, Glencoe IL, The Free Press, 1961, pp. 120-129.

. (1964), "Evolutionary universals in society". American Sociological Review, 29 (16): 339-357.

PAULUS, Andreas. (2001), Eine Untersuchung zur Entwicklung des Völkerrechts im Zeitalter der Globalisierung. München, Beck.
PETERS, Anne. (2006), "Compensatory constitutionalism: the function and potential of fundamental international norms and structures". Leiden Journal of International Law, 19: 579-610.

PIAGET, Jean. (1973), Das moralische Urteil beim Kinde. Frankfurt am Main, Suhrkamp.

PRIEN, Thore. (2010), Fragmentierte Volkssouveränität - Recht, Gerechtigkeit und der demokratische Einspruch in der Weltgesellschaft. Baden-Baden, Nomos.

RISSE, Thomas; ROPP, Stephen C. \& SIKKINK, Kathryn (eds.). (1999), The power of human rights. Cambridge, Cambridge University Press.

ROOSEVELT, Franklin D. (1936), "Speech for the democratic national convention". Public Papers, 5.

(1950), "Message to the Congress, January 4, 1941", in Samuel Rosenman (ed.), The public papers and addresses of Franklin D. Roosevelt. Nova York, Harper, vol. 9.

(2004), "Message to the Congress on the State of the Union, 11 January 1944", in Sunstein, The second Bill of Rights, Nova York, Basic Books, pp. 235-244.

ROSENMAN, Samuel I. (1952), Working with Roosevelt. Nova York, Harper.

SASSOON, Donald. (1996), One hundred years of socialism: the West European left in the Twentieth Century. Nova York, New Press, vol. 1.

SCHATZ, Klaus. (1990), Der päpstliche Primat. Würzburg, Echter.

SEAGLE, W. (1951), Weltgeschichte des Rechts. München/Berlim 1951 [The Quest of Law, Nova York 1941].

SELLIN, Volker. (2001), Die geraubte Revolution. Göttingen, Vandenhoek.

SHAW, Martin. (2000), Theory of the global State: globality as unfinished revolution. Cambridge, Cambridge University Press.

SKUBISZEWSKI, Krysztof. (1989), "Implied powers of international organizations", in Yoram Dinstein e Mala Tabory (eds.), Essays in honour of Shabtai Rosenne. Doodrecht, Nijhoff, pp. 855-868.

STICHWEH, Rudolf. (2000a), "Zur Theorie der Weltgesellschaft", in Die Weltgesellschaft, Frankfurt am Main, Suhrkamp. 
. (2000b), Die Weltgesellschaft. Frank-

furt am Main, Suhrkamp. . (2004), "Der Zusammenhalt der Weltgesellschaft: Nicht-normative Integrationstheorien in der Soziologie", in Jens Beckert, Julia Eckert, Martin Kohli e Wolfgang Streek (eds.), Transnationale Solidarität. Chancen und Grenzen. Frankfurt am Main: Campus, pp. 236245.

STRAYER, Joseph Reese. (1956), "Philip the fair: a 'Constitutional' King”. AHR, 62: 18-32. (1970), On the medieval origins of the modern State. Princeton, Princeton University Press.

STRUVE, Tilman. (2004), Staat und Gesellschaft im Mittelalter. Berlim, Dunker \& Humblot.

SUNSTEIN, Cass R. (2004), The second Bill of Rights. Nova York, Basic Books.

TEUBNER, G. (2003), "Globale Zivilverfassungen”. Zentralarchiv für öffentliches Recht und Völkerrecht, 63: 1-28.

TIERNEY, Brian. (1982), Religion, law, and the growth of constitutional thought 1150-1650. Cambridge, Cambridge University Press.

TILLY, Charles. (1990), Coercion, capital, and European States, AD 990-1990. Malden MA, Basil Blackwell.

(1995), European revolutions 14921992. Oxford, Blackwell.

(2007), "States, State transformation, and war", in Jerry Bently (ed.), The Oxford handbook of world history, Nova York, Columbia University (no prelo, citado a partir do manuscrito).

TOMUSCHAT, Christian. (1993), "Obligations arising for States without or against their Will”. Receueil des Cours, 241: 195-374.

. (1995), "Die internationale Gemeinschaft”. Archiv des Völkerrechts, 33: 1-20.

VERDROSS, Alfred. (1926), Die Verfassung der Völkerrechtsgemeinschaft. Vienna, Julius Springer. . (1971), Die Quellen des universellen Völkerrechts: Eine Einführung. Breisgau, Rombach.

VERDROSS, A. \& SIMMA, Bruno. (1984), Universelles Völkerrecht. Berlim, Dunker \& Humblot.
VESTER, Michael. (1970), Die Entstehung des Proleatariats als Lernprozeß. Frankfurt am Main, EVA.

WEBER, Max. (1964), Wirtschaft und Gesellschaft. Köln, Kiepenheuer. . (1978), Gesammelte Aufsätze zur Religionssoziologie I. Tübingen, Mohr.

WESEL, Uwe. (1997), Geschichte des Rechts. Munique, Beck.

WIEACKER, Franz. (1967), Privatrechtsgeschichte der Neuzeit. Göttingen, Vandenhoeck.

WÜST, Anja. (2007), Das völkerrechtliche Werk von Georges Scelle im Frankreich der Zwischenkriegszeit. Baden-Baden, Nomos. 